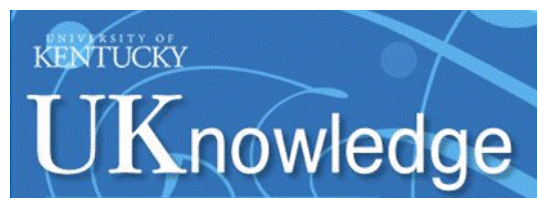

University of Kentucky

UKnowledge

Sanders-Brown Center on Aging Faculty

Publications

Aging

$11-2015$

\title{
ABCC9/SUR2 in the Brain: Implications for Hippocampal Sclerosis of Aging and a Potential Therapeutic Target
}

\author{
Peter T. Nelson \\ University of Kentucky, pnels2@email.uky.edu \\ Gregory A. Jicha \\ University of Kentucky, gregory.jicha@uky.edu \\ Wang-Xia Wang \\ University of Kentucky, wwangc@uky.edu \\ Eseosa T. Ighodaro \\ University of Kentucky, eseosa.ighodaro@uky.edu \\ Sergey C. Artiushin \\ University of Kentucky, scarti1@uky.edu
}

See next page for additional authors

Follow this and additional works at: https://uknowledge.uky.edu/sbcoa_facpub

Part of the Biostatistics Commons, Geriatrics Commons, and the Neurosciences Commons

Right click to open a feedback form in a new tab to let us know how this document benefits you.

\section{Repository Citation}

Nelson, Peter T.; Jicha, Gregory A.; Wang, Wang-Xia; Ighodaro, Eseosa T.; Artiushin, Sergey C.; Nichols, Colin G.; and Fardo, David W., "ABCC9/SUR2 in the Brain: Implications for Hippocampal Sclerosis of Aging and a Potential Therapeutic Target" (2015). Sanders-Brown Center on Aging Faculty Publications. 95. https://uknowledge.uky.edu/sbcoa_facpub/95

This Article is brought to you for free and open access by the Aging at UKnowledge. It has been accepted for inclusion in Sanders-Brown Center on Aging Faculty Publications by an authorized administrator of UKnowledge. For more information, please contact UKnowledge@lsv.uky.edu. 


\section{ABCC9/SUR2 in the Brain: Implications for Hippocampal Sclerosis of Aging and a Potential Therapeutic Target}

Digital Object Identifier (DOI)

https://doi.org/10.1016/j.arr.2015.07.007

Notes/Citation Information

Published in Ageing Research Reviews, v. 24, part B, p. 111-125.

Copyright $\odot 2015$ Elsevier B.V.

(c) 2015. This manuscript version is made available under the CC-BY-NC-ND 4.0 license

http://creativecommons.org/licenses/by-nc-nd/4.0/.

The document available for download is the authors' post-peer-review final draft of the article.

Authors

Peter T. Nelson, Gregory A. Jicha, Wang-Xia Wang, Eseosa T. Ighodaro, Sergey C. Artiushin, Colin G. Nichols, and David W. Fardo 


\title{
ABCC9/SUR2 in the brain: implications for hippocampal sclerosis of aging and a potential therapeutic target
}

\author{
Peter T. Nelson, MD, PhD ${ }^{1,2}$, Gregory A. Jicha, MD, PhD ${ }^{1,3}$, Wang-Xia Wang, $\mathrm{PhD}^{1}$, Eseosa \\ Ighodaro, BS ${ }^{1}$, Sergey Artiushin, PhD ${ }^{1}$, Colin G. Nichols, $\mathbf{P h D}^{4}$, and David W. Fardo, $\mathbf{P h D}^{1,5}$ \\ ${ }^{1}$ Sanders-Brown Center on Aging, University of Kentucky, Lexington, KY, 40536, USA \\ 2Department of Pathology, University of Kentucky, Lexington, KY, 40536, USA \\ ${ }^{4}$ Department of Neurology, University of Kentucky, Lexington, KY, 40536, USA \\ ${ }^{4}$ Center for the Investigation of Membrane Excitability Diseases, Washington University School of \\ Medicine, Saint Louis MO 63110 \\ ${ }^{5}$ Department of Biostatistics, University of Kentucky, Lexington, KY, 40536, USA
}

\begin{abstract}
The $A B C C 9$ gene and its polypeptide product, SUR2, are increasingly implicated in human neurologic disease, including prevalent diseases of the aged brain. SUR2 proteins are a component of the ATP-sensitive potassium ("K $\mathrm{KTP}_{\mathrm{AT}}$ ) channel, a metabolic sensor for stress and/or hypoxia that has been shown to change in aging. The $\mathrm{K}_{\mathrm{ATP}}$ channel also helps regulate the neurovascular unit. Most brain cell types express SUR2, including neurons, astrocytes, oligodendrocytes, microglia, vascular smooth muscle, pericytes, and endothelial cells. Thus it is not surprising that $A B C C 9$ gene variants are associated with risk for human brain diseases. For example, Cantu syndrome is a result of $A B C C 9$ mutations; we discuss neurologic manifestations of this genetic syndrome. More common brain disorders linked to $A B C C 9$ gene variants include hippocampal sclerosis of aging (HS-Aging), sleep disorders, and depression. HS-Aging is a prevalent neurological disease with pathologic features of both neurodegenerative (aberrant TDP-43) and cerebrovascular (arteriolosclerosis) disease. As to potential therapeutic intervention, the human pharmacopeia features both SUR2 agonists and antagonists, so $A B C C 9 / \mathrm{SUR} 2$ may provide a "druggable target", relevant perhaps to both HS-Aging and Alzheimer's disease. We conclude that more work is required to better understand the roles of $A B C C 9 / \mathrm{SUR} 2$ in the human brain during health and disease conditions.
\end{abstract}

\footnotetext{
Corresponding Author: Peter T. Nelson MD PhD, Department of Pathology, Division of Neuropathology, Rm 311, Sanders-Brown Center on Aging, 800 S. Limestone Avenue, University of Kentucky, Lexington, KY 40536-0230, Tel: 859.218.3862, pnels2@email.uky.edu.

Publisher's Disclaimer: This is a PDF file of an unedited manuscript that has been accepted for publication. As a service to our customers we are providing this early version of the manuscript. The manuscript will undergo copyediting, typesetting, and review of the resulting proof before it is published in its final citable form. Please note that during the production process errors may be discovered which could affect the content, and all legal disclaimers that apply to the journal pertain.
} 


\section{Keywords}

SUR2A; SUR2B; SUR2Ab; SUR1; neuropathology; GWAS; hippocampus; oldest-old; arteriolosclerosis; $\mathrm{ABCC} 8$

\section{Introduction}

Hippocampal sclerosis of aging (HS-Aging) (Nelson, et al., 2014,Nelson, et al., 2015) is a common age related brain disorder, characterized by cognitive deterioration that mimics Alzheimer disease (AD) clinically but has a different brain histopathology, a distinctive genetic predisposition, and a later age range for maximal risk (Brenowitz, et al., 2014,Murray, et al., 2014,Nelson, et al., 2013,Zarow, et al., 2012). Although HS-Aging and AD are challenging to distinguish in a living patient (Brenowitz, et al., 2014,Pao, et al., 2011,Yu, et al., 2015), it is likely that each disease will require different strategies for prevention or treatment. The underlying pathogenesis of HS-Aging is unknown currently, but there are indications that the $A B C C 9$ gene may play a key role. This review will summarize what is known about the $A B C C 9$ gene in the human brain and describe our hypothesis linking $A B C C 9$ with HS-Aging. We consider the relevant genetic and evolutionary biologic literature, along with current understanding of $A B C C 9$ function and how the gene may be related to other human diseases.

\section{$A B C C$ genetic phylogeny and the role of $A B C C 9$ paralogs in human diseases}

$A B C C 9$ (ATP-binding cassette, sub-family $\mathrm{C}$ member 9) gene products are referred to as sulfonylurea receptor 2 (SUR2) proteins. The term "sulfonylurea receptor" derives from the fact that sulfonylurea drugs bind to and block protein activity. Thus we employ established terminology referring to the $A B C C 9$ gene, which serves as the template for $S U R 2 \mathrm{mRNA}$ and SUR2 protein (Nichols, et al., 2013,Shi, et al., 2012). SUR2 regulates potassium (K+) channels in plasma membrane and intracellular organelles (Fig. 1), and other aspects of genomic regulation and protein function are described in greater detail below.

Themes emerge to shed light on human $A B C C 9$ from studies in other species. The "ABC" gene cluster encode large transmembrane proteins and members of this gene family have been identified from every biologic phylum including bacteria (Cui and Davidson, 2011,Igarashi, et al., 2004). Each gene encodes polypeptides with the same basic unit being one or two nucleotide binding domains (NBD), each associated with a conserved transmembrane domain (TMD) (Igarashi, et al., 2004). Historically, the ABCC sub-cluster was termed "multidrug-resistant associated proteins" because of the ability of some ABCC proteins to extrude drugs and toxins from cells (Bouige, et al., 2002,S.F. Zhou, et al., 2008). The "SUR"-subclass of ABCC genes contain a pair of TMD-NBD domains, with a unique third TMD (TMD0, Fig. 2). SUR genes encode a subtype of K+ channel regulators, and K+ channels are the most widely expressed ion channel among biologic species (Littleton and Ganetzky, 2000) with a broad range of functions. 
Absent in plants and fungi, direct SUR gene orthologs are numerous in invertebrate species (Frey, et al., 1998,Sturm, et al., 2009), and these genes provide clues about the evolutionarily ancient SUR gene functions. In D. melanogaster, for example, a direct SUR ortholog was identified (Dermauw and Van Leeuwen, 2014). This "dSUR" gene has been implicated in aging, metabolism (including lipid processing and insulin signaling), sleep, and survival after infection or stress (Akasaka, et al., 2006,Allebrandt, et al., 2013,Croker, et al., 2007,Nasonkin, et al., 1999, Ocorr, et al., 2007). There are intriguing results that indicate that dSUR plays a role in aging; the gene is important in the cardiac hypoxic stress response but downregulated in aging (Akasaka, et al., 2006,Nishimura, et al., 2011,Ocorr, et al., 2007). The spider $T$. urticae harbors the largest number of ABCC subfamily member genes of any animal known, including a SUR gene (Dermauw, et al., 2013). The expansive "burst" of ABCC genes in this agricultural pest species may help explain this species' ability to resist pesticidal strategies (Dermauw, et al., 2013). By contrast, some invertebrate species (silkworms) appear to lack direct SUR homologs (Xie, et al., 2012).

Among vertebrate species, two SUR-type paralogs are relatively well conserved -- termed $A B C C 8 /$ SUR 1 and $A B C C 9 /$ SUR2 in humans (Fig. 1). Protein sequence homology between human and zebrafish SUR2 is 79-80\% (Fig. 3). It is clear from genetic manipulation that these SUR genes play phylogenetically durable roles in multiple organs and tissues, including stress response, metabolism, and regulation of blood vessel function (Babenko, et al., 1998,Bryan, et al., 2007,Flatt, et al., 1994,Seino, et al., 2000,Seino and Miki, 2003,Solbach, et al., 2006). Interestingly, there have been shown to be age-dependent changes in KATP channels in a number of species including humans (Bao, et al., 2013,Du, et al., 2013,Kawano, et al., 2010,Toyoda, et al., 1997,Tricarico, et al., 1997,Vajapey, et al., 2014). As discussed below, the molecular basis of their function is understood to be primarily as $\mathrm{K}+$ channel regulators(Nichols, 2006), but there are multiple studies suggesting additional actions that may contribute to the wide physiological impact. ABCC8/SUR1 function is best understood in its role in the vertebrate pancreas and central neuronal tissue, as a controller of insulin secretion and neuronal excitability. In non-mammalian vertebrates, the ABCC9/SUR2 orthologs (sur2), in both goldfish (Carassius auratus), and in yellowtail flounder (Limanda ferruginea), are reported to participate in those species' cardiac hypoxic stress response (Cameron, et al., 2013,MacCormack and Driedzic, 2002). Some neurobiological functions have also been implicated for SUR2 in non-mammalian vertebrates. For example, experiments in frogs showed that SUR modifying drugs impacted the neuromuscular junction presynaptically (Salgado, et al., 1993). In chickens, an opioid signaling cascade includes SUR2 modulation (Tu, et al., 2008).

Additional clues about potential physiological and pathogenetic roles are provided by $A B C C 9$ paralogs in the human genome, presumed to have evolved from a common ancestral gene, that are associated with altered risk for human diseases. For example, mutations of $A B C C 7 / C F T R$ cause cystic fibrosis, the most common fatal genetic disease in Americans (Riordan, et al., 1989). In comparison to $A B C C 7, A B C C 8 / S U R 1$ is far more homologous to $A B C C 9 / S U R 2$ (Fig. 3). ABCC8 is considered to be more highly expressed in the human brain than $A B C C 9$ (Shi, et al., 2005), and $A B C C 8 /$ SUR1 has been implicated in neuropathologic processes (Jiang, et al., 2007,Mehta, et al., 2013,Simard, et al., 
2008a,Simard, et al., 2008b,Simard, et al., 2012,Tosun, et al., 2013). Mutations in ABCC8 are associated with congenital hyperinsulinism and diabetes (Bonfanti, et al., 2015,Bryan, et al., 2007,Efferth, 2003,Haghverdizadeh, et al., 2014,Remedi and Nichols, 2009,Smith, et al., 2007). In the latter case, more severe mutations are associated with a complex syndrome (Developmental delay, Epilepsy and Neonatal diabetes, DEND), in which CNS excitability is aberrant, as a result of hyperactivity of the SUR1-regulated $\mathrm{K}_{\mathrm{ATP}}$ channel activity. That the same disease can result both from mutations in $\mathrm{ABCC} 8$ and in the associated $\mathrm{K}+$ channel pore gene, KCNJ11/Kir6.2, located nearby in Chromosome 11p (Fig. 1)(Busiah, et al., 2013,Florez, et al., 2004,Gloyn, et al., 2003,Koster, et al., 2008,Laukkanen, et al., 2004,Nielsen, et al., 2003,van Dam, et al., 2005) underscoring the complex interconnectedness of the SUR genes with their K+ channels (Bonfanti, et al., 2015,Inoue, et al., 1997, Olson and Terzic, 2010).

We can summarize three themes relevant to human $A B C C 9$ functions, based on studies of other genes and organisms. First, bona fide SUR genes expressed in invertebrates have been associated with diverse functions including resistance to various stressors and neurotoxins. Second, multiple genes of the ABCC cluster, that share characteristics with ABCC9, are associated with human disease conditions including neuropathological outcomes. And finally, among vertebrates, 2 SUR and 2 Kir proteins are strongly conserved, widely expressed, and closely interconnected in function.

\section{$A B C C 9 / S U R 2$ function: biochemistry and physiology}

SUR proteins provide regulatory subunits of $\mathrm{K}_{\mathrm{ATP}}$ channels which respond to metabolic perturbations (Minami, et al., 2004,Nichols, 2006). A complex interplay has been characterized between ATP inhibition, via an interaction with the pore-forming subunit, and ADP-dependent activation, via interaction with the NBDs of the SUR subunit. These activities result in channel sensitivity to local metabolic state -- opening when the ratio of ATP/ADP is low. By blocking or enhancing the ADP (activation) effect, the compendium of pharmacologic agonists and antagonists, many of which are used extensively in humans (de Weille, et al., 1989,Isomoto and Kurachi, 1997,Jackson and Bressler, 1981a,Jackson and Bressler, 1981b,Melander, et al., 1989,Misler and Giebisch, 1992,Stowers and Borthwick, 1977), interact directly with the SUR subunits.

Biochemical and biophysical studies indicate that the functional $\mathrm{K}_{\mathrm{ATP}}$ channel is an octamer consisting of four pore-forming Kir6 proteins, each associated with one SUR subunit (Clement, et al., 1997,Shyng and Nichols, 1997) . The association is necessary for the complex to traffic to the cell membrane: both SUR and Kir6 proteins contain polybasic sequences that act as endoplasmic reticulium retention signals, which are effectively masked when the two proteins are associated (de Araujo, et al., 2011,Lodwick, et al., 2014,Nichols, 2006,Park, et al., 2008,Park and Terzic, 2010). The genes that encode these proteins are shown in Fig. 1, and the understood geometric dispositions of the various proteins depicted in cartoon form. Although biochemical regulation of the $\mathrm{K}_{\mathrm{ATP}}$ channel function is incompletely understood, particularly in the brain, a number of post-translational modifications have been reported. For example, SUR2 is affected directly by glycosylation, sulfhydration, and protein kinase A phosphorylation (Gade, et al., 2013, Gao, et al., 
2014,Kang, et al., 2014,Light, 1996). The $\mathrm{K}_{\mathrm{ATP}}$ channel is also regulated via separate phosphorylation event(s) in the Kir6.x channels (Edwards, et al., 2009,Ko, et al., 2008,Sanada and Kitakaze, 2004,Sun, et al., 2008), again showing complex functional interdependence of these proteins.

RNA splicing, producing alternative $S U R 2$ mRNA transcripts, is a conspicuous feature of ABCC9/SUR2 regulation (Chutkow, et al., 1999,Shi, et al., 2005, Ye, et al., 2009). Reported $A B C C$ 9-derived transcripts are presented in Fig. 4. Most prior studies have focused on two important $S U R 2$ splice variants, which are termed SUR2A and SUR2B. These transcripts are generated through differential splicing of two $A B C C 9$ exons which encode the polypeptides' carboxy terminal portions (Chutkow, et al., 1996,Davis-Taber, et al., 2000,Inagaki, et al., 1996,Isomoto, et al., 1996). SUR2A has been reported to show relatively high expression in cardiac and skeletal muscle cells, whereas $S U R 2 B$ is more broadly expressed including in smooth muscle cells and brain (Chutkow, et al., 1996,Davis-Taber, et al., 2000,Isomoto, et al., 1996,Ploug, et al., 2010,Shi, et al., 2005).

A poorly understood RNA splicing event skips 25 internal $A B C C 9$ exons to produce a smaller gene product that is trafficked to the internal mitochondrial membrane (Ye, et al., 2009). This "mitoSUR" protein variant $(\sim 55 \mathrm{kDa})$ is approximately one third the size of "full-length" SUR2 (Figs. 2B, 4G) and the pharmacologic properties are profoundly different from the larger daughter proteins of $A B C C 9$ (Liu, et al., 2001). The mitoSUR has been described in many contexts including mammalian brain (Aggarwal, et al., 2010,Aggarwal, et al., 2013,Fahrenbach, et al., 2014,Lacza, et al., 2003,Maack, et al., 2009). Genetic lesions in ABCC9 may also differentially affect the expression/splicing, or function, of mitoSUR, SUR2A, and/or SUR2B depending on sequence location. There are other SUR2 transcripts for which the protein products' functions are essentially unknown (Fig. 4), and these observations underscore the necessity for obtaining more basic information about ABCC9.

Experimental studies have elucidated numerous functions for $\mathrm{K}_{\mathrm{ATP}}$ channels, varying by cell-specific, developmental, metabolic, and stress related factors. Here we show schematic diagrams depicting current hypotheses that may be relevant to human brain $\mathrm{K}_{\mathrm{ATP}}$ channels (Figs 5-7). Each figure represents a different paradigm where SUR2 is involved in response to different stimuli and to changes in environment.

In many different cell types, SUR2 may compensate for stress and/or hypoxia by changing membrane hyperpolarization toward a voltage state that attenuates local intracellular $\mathrm{Ca}^{++}$ levels (Fig. 5). Much of the published experimental work to date has focused on cardiac myocytes, where $\mathrm{K}_{\mathrm{ATP}}$ channels are involved in the important paradigm of "ischemic preconditioning" (Rana, et al., 2015,Sanada and Kitakaze, 2004), a term that refers to experimentally induced resistance to the adverse impact of loss of blood supply. Similar paradigm(s) probably occur in human CNS (Alkan, 2009,Busija, et al., 2008,Yuan, et al., 2004). In the vascular smooth muscle cell within the media layer of arterioles (Fig. 6), the $\mathrm{K}_{\mathrm{ATP}}$ channels transmit signals from blood-borne and local factors to modulate blood flow. Notably, this cartoon ignores other members of the neurovascular unit such as endothelial cells, pericytes, and astrocytes, which express $\mathrm{K}_{\mathrm{ATP}}$ channels also (see below). Finally, in 
the CNS (Fig. 7), multiple cell types express SUR2 (see below) and the pleitropic effects of the gene may include neurotransmitter-responsive excitability (Sun and $\mathrm{Hu}, 2010$ ). There is a recurrent theme of SUR2 proteins sensing $\mathrm{Mg}^{++}$/ADP levels to promote $\mathrm{K}_{\mathrm{ATP}}$ channels' opening and local $\mathrm{Ca}^{++}$processing; however, the physiologic result varies widely according to the microenvironment.

\section{$A B C C 9$ in the brain}

Specific $\mathrm{K}_{\mathrm{ATP}}$ channel functions are challenging to define experimentally because of complexity at many levels: the variable components in mature $\mathrm{K}_{\mathrm{ATP}}$ channels, different splice variants of both SUR proteins, functional changes that may result from altered intracellular trafficking, post-translational modifications, and the idiosyncrasies of channel functions from cell type to cell type. A recent review listed over 50 different $\mathrm{K}+$ channel proteins in the mammalian CNS, and acknowledged formidable "challenges presented by the combined molecular complexity of [K+ channels] and structural complexity of the mammalian brain" (Trimmer, 2015). That review article focused on the pore-forming $\mathrm{K}+$ channel proteins so $A B C C 9 / \mathrm{SUR} 2$ was not mentioned. As stated above, $\mathrm{K}_{\mathrm{ATP}}$ channels may be composed of mixtures of regulatory (SUR1/SUR2) and pore-forming (Kir6.1/Kir6.2) subunits (Wheeler, et al., 2008,Yoshida, et al., 2004) and each combination has different attributes (Cheng, et al., 2008, Yamada, et al., 1997) although there may be constraints on the combinatorial potential of an individual channel complex (Giblin, et al., 2002). A discussion of some of the characteristics of the various $\mathrm{K}_{\mathrm{ATP}}$ channel assemblages is presented elsewhere (Babenko, et al., 1998). Relatively little is known about the gene regulatory orchestration of the biologically integrated channel components in brain. Interestingly, the human SUR2 3'UTR is variable in length (al) which may be a pathway for regulating transcript stability (Nelson and Keller, 2007). Further, mouse Sur1 and Sur2 expression can be regulated through promoter DNA methylation (Fatima, et al., 2012).

A fundamental question is -- which cells express the mRNA and proteins? In brief, SUR2 is likely expressed in every cell type of the human brain, including neurons, astrocytes, oligodendrocytes, ependymal cells, microglia, pericytes, vascular smooth muscle, and endothelial cells. It is a common overgeneralization that SUR2A is a skeletal and cardiac muscle protein whereas SUR2B is a vascular smooth muscle protein -- the actual expression pattern of SUR2 isoforms is less straightforward. One of the technical limitations to the study of $A B C C 9 / \mathrm{SUR} 2$ is the lack of "gold-standard" molecular probes that could characterize comprehensively the subtypes of $A B C C$ 9-derived transcripts and polypeptides that are expressed. From the perspective of lab bench researchers that have assessed the results of multiple SUR2 antibodies, we can attest to the imperfect apparent specificity of some of these probes in our hands (see Ref. (Nelson, et al., 2014)). Prior studies of SUR2 gene expression focused on non-human mammals. Zhou et al (Zhou, et al., 2012) studied SUR2 distribution (mRNA and protein) in rat brain and found widespread expression; neurons predominantly expressed SUR2A whereas SUR2B was more expressed in glial cells. Interestingly, arteries from different anatomical areas of pig brains also were reported to show distinctive profiles of SUR2A and SUR2B expression (Jansen-Olesen, et al., 2005,Ploug, et al., 2006,Ploug, et al., 2008). Probes that were not isoform-specific demonstrated SUR2 protein in rat dorsal root ganglia neurons (Zoga, et al., 2010), and, a 
study of hippocampal neurons using single-cell PCR showed that SUR2 expression was more common among hippocampal interneurons than pyramidal-type excitatory neurons (Zawar, et al., 1999). Experiments in cultured primary rat neurons also found substantial SUR2 expression (Ma, et al., 2009). A different study of rats showed that neuronal SUR2 expression (both mRNA and protein level) increased following neurotoxin lesions in the prefrontal cortex (S. Wang, et al., 2005).

Looking beyond anatomical and cellular distribution patterns, assessment of the functional roles of $A B C C 9 / \mathrm{SUR} 2$ in the mammalian brain is also confounded by the imperfect specificity of many of the experimental approaches. For example, most of the drugs that impact SUR2, including glibenclamide, also affect SUR1. Many prior studies- in the substantia nigra, in the hypothalamus, and elsewhere have focused on SUR1. Single cell RTPCR indicates that the $\mathrm{K}_{\mathrm{ATP}}$ channels in those cells are probably comprised primarily of SUR1 and Kir6.2 (Hicks, et al., 1994,Lee, et al., 2011,Liss, et al., 1999,Wu, et al., 1996), but over-reliance on the sulfonylurea marker [3H-Glibenclamide] may detect SUR2 as well as SUR1, and genetic manipulations in rodents have focused on the Kir6.x genes, which do not distinguish between Sur1 or Sur2 partner proteins.

Although there is evidence to indicate $A B C C 9 /$ SUR2-related mechanisms are important for neuron (Ma, et al., 2008,Ma, et al., 2009,Tanner, et al., 2011,Xie, et al., 2010,Zawar, et al., 1999), astrocyte (Wang, et al., 2014,Zhou, et al., 2012,Zhu, et al., 2008), and oligodendrocyte (Fogal, et al., 2010) function, there are presently more bases for a discussion of the published literature regarding the impact of $A B C C 9 / \mathrm{SUR} 2$ on brain vasoregulation. SUR2 may contribute in multiple ways to the complicated task of regulating CNS blood flow and neuroinflammation. In particular, $\mathrm{K}_{\mathrm{ATP}}$ channels have been shown to play important roles in vascular smooth muscle cells (Ko, et al., 2008,Nichols, et al., 2013,Shi, et al., 2012,Standen and Quayle, 1998,Sun and Hu, 2010) including primary effects of vasoactive diffusible factors (nitric oxide and hydrogen sulfide) (Liang, et al., 2011,Shi, et al., 2012,Wang, et al., 2014). SUR2-containing $\mathrm{K}_{\text {ATP }}$ channels are biochemical substrates partly responsible for vasodilation following oxygen and/or glucose deprivation (Adebiyi, et al., 2011). There have been relatively few study of brain arterioles in association with genetic or pharmacologic manipulations of SUR2 per se. However, smooth muscle cells are not the only cell type of the neurovascular unit that express $A B C C 9$; for example, SUR2B was identified as upregulated in rat capillaries of stroke-prone spontaneously hypertensive rats and hypothesized to contribute to their endothelial dysfunction (Kirsch, et al., 2001). Further, in mouse embryo brains, $A B C C 9$ is robustly expressed in the pericytes (Bondjers, et al., 2006). Finally, there are multiple lines of evidence that $\mathrm{K}_{\mathrm{ATP}}$ channels help regulate inflammatory signaling in microglia. SUR2B may modulate the microglial release of pro-inflammatory factors including TNF-alpha and reactive oxygen species (Sun and Hu, 2010). Microglia appear to activate a microglial>neuronal precursor mechanism that includes $\mathrm{K}_{\mathrm{ATP}}$ channel activation (Ortega, et al., 2012,F. Zhou, et al., 2008). However, many of the above studies are confounded by both technical and theoretical complexities that render an "overview" challenging.

A perspective on prior discoveries related to $A B C C 9 / \mathrm{SUR} 2$ in the brain, along with insights into therapeutic potential, may be conveyed through a cross-section of the reports that 
focused on a particular drug candidate molecule, iptakalim (systematic name: 2, 3-dimethyl$\mathrm{N}$-[1-methylethyl]-2-butanamine). Iptakalim is an "atypical $\mathrm{K}_{\mathrm{ATP}}$ channel opener" agent that is administered orally and penetrates the blood-brain barrier, with pharmacologic activation of $\mathrm{K}_{\mathrm{ATP}}$ channels that varies by SUR protein types: SUR2B>SUR2A>>SUR1 (Costa, 2009,Gao, et al., 2005,Sikka, et al., 2012). Iptakalim has been shown to exert effects that hint at the potential for clinical benefits. The drug is neuroprotective in experimental models of stroke and Parkinson's disease (Hu, et al., 2005,H. Wang, et al., 2005a,H. Wang, et al., 2005b,Wang, et al., 2004,S. Wang, et al., 2005,Wang, et al., 2006, Yang, et al., 2004,Yang, et al., 2005,Yang, et al., 2009,Zhang, et al., 2011,Zhou, et al., 2007). Other experimental results reported for iptakalim in mammals include beneficial neurochemical effects that may help to combat depression or psychoses (Lu, et al., 2014,Volf, et al., 2012). Preliminary clinical trials have indicated lack of adverse side effects in human research volunteers (Cai, et al., 2012,Duan, et al., 2011). Much remains to be learned about the potential therapeutic and/or side effects of iptakalim.

\section{$A B C C 9$ gene variants in human diseases: overview}

For iptakalim or any drug, exhaustive biologic characterization is not a necessary prerequisite to developing a therapeutic strategy. There are many examples of drugs whose safety and efficacy were determined prior to full insights into drug mechanism(s). This may be kept in mind as we shift topics, from the incompletely understood $A B C C 9$ mechanisms of action, and toward a description of human diseases that are linked to the gene.

Multiple $A B C C 9$ allelic variants are associated with human diseases. A genetic disease condition called hypertrichotic osteochondrodysplasia, or Cantu syndrome (Harakalova, et al., 2012, van Bon, et al., 2012), is caused by heterozygous ABCC9 mutations that so far are clustered in the exons encoding the core of SUR2 (Czeschik, et al., 2013,Harakalova, et al., 2012,van Bon, et al., 2012) and therefore will be expressed in SUR2A and SUR2B (Grange, et al., 2014,Nichols, et al., 2013). Cantu syndrome is rare with $<100$ cases reported to date (Scurr, et al., 2011) (see below). The clinical features include disorders of bones, heart, and hair follicles (hirsuitism) with macrocephaly often observed (Cantu, et al., 1982,Nevin, et al., 1996). Whereas the reasons for the manifestations are not known, the mechanism for Cantu syndrome is gene gain-of-function, reducing the sensitivity of channel activation to the ADP/ATP ratio (Nichols, et al., 2013). While ABCC8 or KCNJ8 gene deletion in mice results in a Prinzmetal angina-like phenotype with elevated blood pressures (Chutkow, et al., 2002,Li, et al., 2013,Miki, et al., 2002), no specific human monogenic syndrome has yet been definitively linked to loss-of-function mutations in $A B C C 9$.

Of direct relevance to the current review, prior published reports all lack neuropathologic workup, but underscore that this disease often includes neurological complications, with a cerebrovascular component documented in some cases (Table 1). Different reports have noted the presence of "mild" mental retardation, autism, intellectual disability, and/ or neuroimaging-based brain abnormalities - at least one of these conditions was noticed in 28/47 (60\%) of Cantu syndrome cases described to date (Table 1). The neurologic developmental delay that can be seen in Cantu syndrome may be partly secondary to skeletal muscle manifestations, i.e. hypotonia (Grange, et al., 2014) or may be related to alterations 
in brain blood flow. Importantly, two mutations in $K C N J 8 /$ Kir6.1 which also result in gainof-function in expressed $\mathrm{K}_{\mathrm{ATP}}$ channels, are associated with Cantu syndrome, along with neurological phenotype with tortuous cerebral blood vessels (Brownstein, et al., 2013,Cooper, et al., 2014).

Whereas Cantu syncrome is a congenital defect that may have pleitropic manifestations, a number of exonic $A B C C 9$ variants have been associated with cardiovascular diseases including atrial fibrillation, vasospasm, dilated cardiomyopathy, and myocardial infarction (Barajas-Martinez, et al., 2012,Beziau, et al., 2014,Bienengraeber, et al., 2004,Kane, et al., 2005,Nichols, et al., 2013,Olson, et al., 2007,Smith, et al., 2013); Table 2. Variants in $A B C C 9$ have also been reported in association with Brugada (cardiovascular) syndrome and early repolarization syndrome (Barajas-Martinez, et al., 2012,Hu, et al., 2014). In prior studies, as with Cantu syndrome cases, there has not been systematic neuropathological nor neuroimaging-based assessment of blood vessels to date in the brains of patients with disease-associated exonic $A B C C 9$ polymorphisms.

In contrast to the results of $A B C C 9$ exonic mutations, intronic single nucleotide polymorphisms (SNPs) have been linked to diverse non-cardiac clinical phenotypes (Table 2). Some genetic associations were reported that are intriguing but did not identify a single particular SNP that met criteria for a statistically significant association with a specific disease. For example, ABCC9 SNPs were associated with Hirschprung disease (most significant SNP was rs704192) in a genomewide association study (GWAS) of 123 persons with "sporadic" Hirschprung disease, and 432 unaffected controls (Kim, et al., 2014). In a separate GWAS with 281 elderly individuals, a SNP (rs 10743430) was associated with entorhinal cortical thinning on magnetic resonance imaging (MRI) (Furney, et al., 2011). Further, 2 reports linked $A B C C 9$ polymorphism with hypertension. Sato et al (Sato, et al., 2006) identified a combination of SNPs that correlate with essential hypertension in a cohort of 405 individuals, and Kamide et al (Kamide, et al., 2013) found in a cohort of 265 persons that an $A B C C 9$ SNP is associated with responses to anti-hypertension drugs.

In terms of genomic studies that reported statistically significant associations between $A B C C 9$ SNPs and human illnesses, these conditions have tended to be brain disorders: sleep problems, depression, and HS-Aging. These SNPs are best considered "risk factors" because the allelic variant shows far lower genetic penetrance than the exonic mutations. The sleep and depression studies come from two separate research groups and the results incompletely overlap. Allebrandt et al (Allebrandt, et al., 2013) found that there is an ABCC9 SNP (rs11046205) associated with sleep duration. A follow-up study by Parsons et al (Parsons, et al., 2013) failed to replicate the primary SNP association but identified a rare polymorphism nearby (rs11046209) that was associated with altered sleep duration and found that rs11046205 status was associated in that sample with depressive symptoms (Parsons, et al., 2013).

\section{ABCC9 in hippocampal sclerosis of aging (HS-Aging)}

The association between $A B C C 9$ genetic polymorphism and HS-Aging suggest a pathogenetic mechanism with substantial impact on public health. HS-Aging is prevalent 
among aged individuals, affecting up to 25\% of the "oldest-old" (Kuslansky, et al., 2004,Leverenz and Lipton, 2008,Murray, et al., 2014,Zarow, et al., 2008,Zarow, et al., 2012). HS-Aging mimics AD clinically (Brenowitz, et al., 2014,Nag, et al., 2015,Pao, et al., 2011), and the association between HS-Aging pathology and antemortem cognitive impairment is strong, factoring in all other known pathologies (Nag, et al., 2015,Nelson, et al., 2010). Importantly, HS-Aging tends to occur in individuals older than 85 years of age at death (Dickson, et al., 1994,Murray, et al., 2014,Nelson, et al., 2011,Nelson, et al., 2013).

The neuropathology of HS-Aging is characterized by cell loss and astrocytosis in the hippocampal formation of aged persons that is out of proportion to the Alzheimer's-type plaques and tangles (Montine, et al., 2012). Focusing on the pathology-based endophenotype, we performed a GWAS and replication experiment that incorporated 363 HS-Aging cases and 2303 controls, from 5 separate large autopsy cohorts, with every case pathologically evaluated (Nelson, et al., 2014). This study yielded only a single statistically significant risk locus for HS-Aging, an ABCC9 SNP pair (rs704178 and rs704180) that are co-inherited. Subsequently, we performed an additional replication assessment of a separate group of individuals with 51 HS-Aging cases and 561 controls (again, all cases were pathologically verified) that replicated the association between rs704180 risk genotype and HS-Aging pathology (Nelson, et al., 2015). Interestingly, there appears to be genetic "hotspot" with common SNPs associated with HS-Aging pathology and other disease phenotypes. For example, the SNP associated with Hirschprung disease (Kim, et al., 2014) -- rs704192 -- is in relatively close linkage disequilibrium to rs704180 $\left(\mathrm{r}^{2}=0.55\right.$, D' statistic 0.91). The SNP associated with both sleep duration and depression (Allebrandt, et al., 2013,Parsons, et al., 2013) -- rs11046205 -- is in the same intron as rs704178, <2000 bases away. We also note that the SNP (rs10743430) that showed association (Furney, et al., 2011) with entorhinal cortical thinning (P 1e-7 but not genomewide significant) is not within the $A B C C 9$ gene itself, but upstream and intergenic. However, evaluation of public access databases indicate that rs 10743430 may be an expression quantitative trait locus for $A B C C 9$ (data not shown).

Prospects for development of therapeutic strategies may be enhanced by better understanding disease mechanisms. A key challenge is determining which disease paradigm best fits for HS-Aging: is it a neurodegenerative disease, or a cerebrovascular disease? Cerebrovascular diseases are characterized by disrupted blood supply, with relatively unpredictable clinical and anatomic disease progression. By contrast, neurodegenerative diseases usually follow a progressive clinical course, with pathognomonic "inclusion bodies" within specific brain areas.

Although the pathogenesis of HS-Aging is incompletely understood, some published findings suggest vascular factors cause or exacerbate the disease. Dickson et al (Dickson, et al., 1994), in a seminal study of 13 aged individuals with hippocampal sclerosis, observed severe "arteriosclerosis" in 12 of the 13 cases, after which others (Reed, et al., 2007, White, et al., 2002,Zarow, et al., 2008) also hypothesized a link between hippocampal sclerosis and cardiovascular risk factors. Subsequent studies have provided a more specific focus. We performed a systematic analysis of multiple large autopsy series and found that among vascular pathologies in the brain, only arteriolosclerosis - dysmorphic changes in small 
arterioles (Fig. 8) - is associated with HS-Aging pathology (Neltner, et al., 2014). In HSAging cases, arteriolosclerosis was observed in regions outside of the hippocampal formation, indicating a "whole-brain disease" rather than a disease process isolated to the medial temporal lobe. Intriguingly, Montagne and colleagues recently showed that subtle blood-brain barrier dysfunction and "leaky vessels" in the human hippocampus precede cognitive impairment in advanced aging (Montagne, et al., 2015). Winkler et al (Sagare, et al., 2013) reported that pericyte damage could contribute to cognitive impairment through disruption of the neurovascular unit, which may relate to HS-Aging rather than AD. ABCC9 has also been shown to be expressed in pericytes and its impairment associated with leaky vessels (Bondjers, et al., 2006), and $\mathrm{K}_{\mathrm{ATP}}$ channels have been shown to be sensitive to cerebral ischemia (Armstead, 1997,Lindauer, et al., 2003,Sun and Hu, 2010).

Alongside the findings linking HS-Aging to cerebrovascular disease, brains of patients with HS-Aging pathology have pathologic features that are indicative of a neurodegenerative condition. A key pathologic biomarker for HS-Aging is aberrant TDP-43 inclusion bodies that may resemble the staining pattern of hippocampal TDP-43 pathology observed in frontotemporal lobar degeneration (FTLD), a neurodegenerative disease (Amador-Ortiz, et al., 2007a,Amador-Ortiz, et al., 2007b,Aoki, et al., 2015,Neumann, et al., 2006). Further, some gene variants (in or near GRN and TMEM106B genes) that are associated with increased risk for HS-Aging (Dickson, et al., 2010,Murray, et al., 2014,Nelson, et al., 2015,Pao, et al., 2011,Rademakers, et al., 2008) were previously associated with increased risk for FTLD (Deming and Cruchaga, 2014,Van Deerlin, et al., 2007). The clinical course of HS-Aging also tends to follow the trajectory of a neurodegenerative disease (Nelson, et al., 2011).

So how could HS-Aging be related to both cerebrovascular disease and neurodegenerative disease? The ABCC9 genetic association may be a critical clue to help solve the riddle.

Although there are valid reasons to contradistinguish neurodegenerative and cerebrovascular disorders, there is increasing evidence in support of a more nuanced paradigm with "mixed" pathogenetic mechanisms in the aged human brain (Montine, et al., 2014,Snyder, et al., 2014,Weller, et al., 2015). TDP-43 pathology is not specific for neurodegenerative diseases, having been reported in a wide variety of brain disorders including Alexander's disease, Down syndrome, low-grade glial neoplasms, and chronic brain trauma (Davidson, et al., 2011,Lee, et al., 2008,Ling, et al., 2013,McKee, et al., 2010,Walker, et al., 2014), so there is overlap between pathologic findings that are seen in "reactive" and "neurodegenerative" conditions. Note that in each of the above conditions there is a brain injury or disease that occurs over a long time period, as opposed to an acute condition. It is quite possible that a subtype of chronic vascular insult(s) could induce TDP-43 phosphorylation and misfolding, although acute anoxic or hypoxic changes lack TDP-43 pathology (Amador-Ortiz, et al., 2007b,Lee, et al., 2008,Nelson, et al., 2011,Zarow, et al., 2008). Conversely, many vascular abnormalities have been described in AD brains (Brown and Thore, 2011,Farkas and Luiten, 2001,Hamel, 2014,Hunter, et al., 2012,Kalaria, et al., 2012). The established functions of human $A B C C$ 9/SUR2 include both regulating arteriolar smooth muscle tone and participating in pathways that have been implicated in neurodegenerative diseases, e.g., hypoxia/ischemia, neuroinflammation, and injury responses. There are also published 
studies that support direct connections between $A B C C 9 /$ SUR2 and neurodegenerative diseases, including both HS-Aging and AD. For example, in a study of Abcc 9 knockout mice, the biological pathway most affected (versus wildtype) was "Alzheimer's disease" (Gao, et al., 2014). Moreover, treatment of mice that model Alzheimer's-type pathology with SUR2 activators causes attenuation of pathology (Goodman and Mattson, 1996,Heurteaux, et al., 1993,Kong and Ba, 2012,Liu, et al., 2002,Liu, et al., 2010,Liu, et al., 2003). There is as yet unclear understandings of the cross-talk between the normal and disease pathways. A very recent paper found direct evidence for $\mathrm{K}_{\mathrm{AT}} \mathrm{P}$ channels regulating brain $\mathrm{A} \beta$ peptide release, and concluded that "the identification of these channels as a link between hyperglycemia and AD pathology creates an avenue for translational research in AD.” (Macauley, et al., 2015)

Data from multiple sources are thus compatible with the novel hypothesis that long-term $A B C C 9$ dysregulation due to a genetic variant may manifest, in the "oldest-old", in a pathologic phenotype that combines features of a cerebrovascular disease (arteriolosclerosis) and a neurodegenerative disease (hippocampal TDP-43 pathology and cell loss). The $\mathrm{K}_{\mathrm{AT}} \mathrm{P}$ channels may also be directly relevant to AD pathology. The details of a stereotypical timeline or causal hierarchy of mechanisms are as yet beyond our grasp but Fig. 8 conveys one plausible hypothesis, and a credible molecular pathway for disease modification.

\section{Going forward: prospects for neurotherapeutic strategies}

$A B C C 9 /$ SUR2 is an attractive candidate for therapeutic strategies because it is wellestablished as a "druggable target". Pharmacological agents that modify SUR function are well known and prescribed widely around the world. Both agonists (nicorandil, diazoxide, iptakalim) and antagonists (sulfonylurea drugs) have been applied in clinical trials. In addition to treatment of monogenic diseases such as Cantu syndrome, such drugs may be repurposed for other human pathologies including cardiovascular diseases, as well as sleep disorders and depression. Currently we have no perfect animal model for HS-Aging to study with these well-characterized drugs. This is an area of active research in our laboratory. An important point about characterized drugs that affect SUR2 function is that each has different specificity for SUR2A, SUR2B, and SUR1, and each could exert different impact on the brain due to blood-brain barrier penetration and other factors (for example, the sulfonylurea drugs tend to be water-insoluble (Davis, et al., 1982,Miralles, et al., 1982)). The overall impact on an organism and/or disease progression is therefore stochastic and more work may be required to engineer drugs tailored to specific targets, and applicable to particular brain functions or diseases.

In summary, the $A B C C 9$ gene, and its polypeptide SUR2 product, occupies an intriguing biological niche relevant to stress response and vasoregulation in the brain. The direct implications for human diseases are most sharply defined for Cantu syndrome, characterized by subtle but intriguing neurological manifestations. Potentially more important in terms of human disease prevalence are the associations between $A B C C 9$ and sleep disorders, depression, and HS-Aging. For now, more understanding of the biology of $A B C C 9 / \mathrm{SUR} 2$ and $\mathrm{K}_{\mathrm{ATP}}$ channels in the human brain is required. Better resources for manipulation and 
assay of $\mathrm{K}_{\mathrm{ATP}}$ channel subcomponents are also needed, in order to realize the potential for positive impact on public health through greater focus on this pathogenetic gene.

\section{Acknowledgment}

The study was supported by NIH grants P30 AG028383, R01 AG038651, R01 AG042419, R01 HL45742, R01 HL95010, K25 AG043546, and T32 AG 000242.

\section{Bibliography}

Adebiyi A, McNally EM, Jaggar JH. Vasodilation induced by oxygen/glucose deprivation is attenuated in cerebral arteries of SUR2 null mice. American journal of physiology Heart and circulatory physiology. 2011; 301(4):H1360-H1368. [PubMed: 21784985]

Aggarwal NT, Pravdic D, McNally EM, Bosnjak ZJ, Shi NQ, Makielski JC. The mitochondrial bioenergetic phenotype for protection from cardiac ischemia in SUR2 mutant mice. American journal of physiology Heart and circulatory physiology. 2010; 299(6):H1884-H1890. [PubMed: 20935152]

Aggarwal NT, Shi NQ, Makielski JC. ATP-sensitive potassium currents from channels formed by Kir6 and a modified cardiac mitochondrial SUR2 variant. Channels. 2013; 7(6):493-502. [PubMed: 24037327]

Akasaka T, Klinedinst S, Ocorr K, Bustamante EL, Kim SK, Bodmer R. The ATP-sensitive potassium (KATP) channel-encoded dSUR gene is required for Drosophila heart function and is regulated by tinman. Proc Natl Acad Sci U S A. 2006; 103(32):11999-12004. [PubMed: 16882722]

Alkan T. Neuroproctective effects of ischemic tolerance (preconditioning) and postconditioning. Turkish neurosurgery. 2009; 19(4):406-412. [PubMed: 19847763]

Allebrandt KV, Amin N, Muller-Myhsok B, Esko T, Teder-Laving M, Azevedo RV, Hayward C, van Mill J, Vogelzangs N, Green EW, Melville SA, Lichtner P, Wichmann HE, Oostra BA, Janssens AC, Campbell H, Wilson JF, Hicks AA, Pramstaller PP, Dogas Z, Rudan I, Merrow M, Penninx B, Kyriacou CP, Metspalu A, van Duijn CM, Meitinger T, Roenneberg T. A K(ATP) channel gene effect on sleep duration: from genome-wide association studies to function in Drosophila. Mol Psychiatry. 2013; 18(1):122-132. [PubMed: 22105623]

Amador-Ortiz C, Ahmed Z, Zehr C, Dickson DW. Hippocampal sclerosis dementia differs from hippocampal sclerosis in frontal lobe degeneration. Acta Neuropathol (Berl). 2007a; 113(3):245252. [PubMed: 17195931]

Amador-Ortiz C, Lin WL, Ahmed Z, Personett D, Davies P, Duara R, Graff-Radford NR, Hutton ML, Dickson DW. TDP-43 immunoreactivity in hippocampal sclerosis and Alzheimer's disease. Ann Neurol. 2007b; 61(5):435-445. [PubMed: 17469117]

Aoki N, Murray ME, Ogaki K, Fujioka S, Rutherford NJ, Rademakers R, Ross OA, Dickson DW. Hippocampal sclerosis in Lewy body disease is a TDP-43 proteinopathy similar to FTLD-TDP Type A. Acta Neuropathol. 2015; 129(1):53-64. [PubMed: 25367383]

Armstead WM. Brain injury impairs ATP-sensitive K+ channel function in piglet cerebral arteries. Stroke; a journal of cerebral circulation. 1997; 28(11):2273-2279. discussion 80.

Babenko AP, Aguilar-Bryan L, Bryan J. A view of sur/KIR6.X, KATP channels. Annual review of physiology. 1998; 60:667-687.

Bao L, Taskin E, Foster M, Ray B, Rosario R, Ananthakrishnan R, Howlett SE, Schmidt AM, Ramasamy R, Coetzee WA. Alterations in ventricular K(ATP) channel properties during aging. Aging Cell. 2013; 12(1):167-176. [PubMed: 23173756]

Barajas-Martinez H, Hu D, Ferrer T, Onetti CG, Wu Y, Burashnikov E, Boyle M, Surman T, Urrutia J, Veltmann C, Schimpf R, Borggrefe M, Wolpert C, Ibrahim BB, Sanchez-Chapula JA, Winters S, Haissaguerre M, Antzelevitch C. Molecular genetic and functional association of Brugada and early repolarization syndromes with S422L missense mutation in KCNJ8. Heart rhythm : the official journal of the Heart Rhythm Society. 2012; 9(4):548-555. [PubMed: 22056721]

Beziau DM, Barc J, O’Hara T, Le Gloan L, Amarouch MY, Solnon A, Pavin D, Lecointe S, Bouillet P, Gourraud JB, Guicheney P, Denjoy I, Redon R, Mabo P, le Marec H, Loussouarn G, Kyndt F, 
Schott JJ, Probst V, Baro I. Complex Brugada syndrome inheritance in a family harbouring compound SCN5A and CACNA1C mutations. Basic research in cardiology. 2014; 109(6):446. [PubMed: 25341504]

Bienengraeber M, Olson TM, Selivanov VA, Kathmann EC, O’Cochlain F, Gao F, Karger AB, Ballew JD, Hodgson DM, Zingman LV, Pang YP, Alekseev AE, Terzic A. ABCC9 mutations identified in human dilated cardiomyopathy disrupt catalytic KATP channel gating. Nature genetics. 2004; 36(4):382-387. [PubMed: 15034580]

Bondjers C, He L, Takemoto M, Norlin J, Asker N, Hellstrom M, Lindahl P, Betsholtz C. Microarray analysis of blood microvessels from PDGF-B and PDGF-Rbeta mutant mice identifies novel markers for brain pericytes. FASEB journal : official publication of the Federation of American Societies for Experimental Biology. 2006; 20(10):1703-1705. [PubMed: 16807374]

Bonfanti DH, Alcazar LP, Arakaki PA, Martins LT, Agustini BC, de Moraes Rego FG, Frigeri HR. ATP-dependent potassium channels and type 2 diabetes mellitus. Clinical biochemistry. 2015

Bouige P, Laurent D, Piloyan L, Dassa E. Phylogenetic and functional classification of ATP-binding cassette (ABC) systems. Current protein \& peptide science. 2002; 3(5):541-559. [PubMed: 12370001]

Brenowitz WD, Monsell SE, Schmitt FA, Kukull WA, Nelson PT. Hippocampal Sclerosis of Aging is a Key Alzheimer's Disease Mimic: Clinical-Pathologic Correlations and Comparisons with both Alzheimer's Disease and Non-Tauopathic Frontotemporal Lobar Degeneration. J Alzheimers Dis. 2014; 39(3):691-702. [PubMed: 24270205]

Brown WR, Thore CR. Review: cerebral microvascular pathology in ageing and neurodegeneration. Neuropathol Appl Neurobiol. 2011; 37(1):56-74. [PubMed: 20946471]

Brownstein CA, Towne MC, Luquette LJ, Harris DJ, Marinakis NS, Meinecke P, Kutsche K, Campeau PM, Yu TW, Margulies DM, Agrawal PB, Beggs AH. Mutation of KCNJ8 in a patient with Cantu syndrome with unique vascular abnormalities - support for the role of K(ATP) channels in this condition. European journal of medical genetics. 2013; 56(12):678-682. [PubMed: 24176758]

Bryan J, Munoz A, Zhang X, Dufer M, Drews G, Krippeit-Drews P, Aguilar-Bryan L. ABCC8 and ABCC9: ABC transporters that regulate K+ channels. Pflugers Archiv : European journal of physiology. 2007; 453(5):703-718. [PubMed: 16897043]

Busiah K, Drunat S, Vaivre-Douret L, Bonnefond A, Simon A, Flechtner I, Gerard B, Pouvreau N, Elie C, Nimri R, De Vries L, Tubiana-Rufi N, Metz C, Bertrand AM, Nivot-Adamiak S, de Kerdanet M, Stuckens C, Jennane F, Souchon PF, Le Tallec C, Desiree C, Pereira S, Dechaume A, Robert JJ, Phillip M, Scharfmann R, Czernichow P, Froguel P, Vaxillaire M, Polak M, Cave H, French NDMsg. Neuropsychological dysfunction and developmental defects associated with genetic changes in infants with neonatal diabetes mellitus: a prospective cohort study [corrected]. The lancet Diabetes \& endocrinology. 2013; 1(3):199-207. [PubMed: 24622368]

Busija DW, Gaspar T, Domoki F, Katakam PV, Bari F. Mitochondrial-mediated suppression of ROS production upon exposure of neurons to lethal stress: mitochondrial targeted preconditioning. Advanced drug delivery reviews. 2008; 60(13-14):1471-1477. [PubMed: 18652858]

Cai Y, Chai D, Pei F, Fang Y, Wang R, Liang BB, Cui WY, Bao CG, Wang H. Single-dose pharmacokinetics and safety of iptakalim hydrochloride in Chinese healthy volunteers. The Journal of pharmacy and pharmacology. 2012; 64(3):337-343. [PubMed: 22309265]

Cameron JS, DeWitt JP, Ngo TT, Yajnik T, Chan S, Chung E, Kang E. Cardiac K(ATP) channel alterations associated with acclimation to hypoxia in goldfish (Carassius auratus L.). Comparative biochemistry and physiology Part A, Molecular \& integrative physiology. 2013; 164(4):554-564.

Cantu JM, Garcia-Cruz D, Sanchez-Corona J, Hernandez A, Nazara Z. A distinct osteochondrodysplasia with hypertrichosis- Individualization of a probable autosomal recessive entity. Hum Genet. 1982; 60(1):36-41. [PubMed: 7076246]

Cheng WW, Tong A, Flagg TP, Nichols CG. Random assembly of SUR subunits in K(ATP) channel complexes. Channels. 2008; 2(1):34-38. [PubMed: 18690055]

Chutkow WA, Makielski JC, Nelson DJ, Burant CF, Fan Z. Alternative splicing of sur2 Exon 17 regulates nucleotide sensitivity of the ATP-sensitive potassium channel. J Biol Chem. 1999; 274(19):13656-13665. [PubMed: 10224138] 
Chutkow WA, Pu J, Wheeler MT, Wada T, Makielski JC, Burant CF, McNally EM. Episodic coronary artery vasospasm and hypertension develop in the absence of Sur2 K(ATP) channels. The Journal of clinical investigation. 2002; 110(2):203-208. [PubMed: 12122112]

Chutkow WA, Simon MC, Le Beau MM, Burant CF. Cloning, tissue expression, and chromosomal localization of SUR2, the putative drug-binding subunit of cardiac, skeletal muscle, and vascular KATP channels. Diabetes. 1996; 45(10):1439-1445. [PubMed: 8826984]

Clement, JPt; Kunjilwar, K.; Gonzalez, G.; Schwanstecher, M.; Panten, U.; Aguilar-Bryan, L.; Bryan, J. Association and stoichiometry of K(ATP) channel subunits. Neuron. 1997; 18(5):827-838. [PubMed: 9182806]

Concolino D, Formicola S, Camera G, Strisciuglio P. Congenital hypertrichosis, cardiomegaly, and osteochondrodysplasia (Cantu syndrome): a new case with unusual radiological findings. Am J Med Genet. 2000; 92(3):191-194. [PubMed: 10817653]

Cooper PE, Reutter H, Woelfle J, Engels H, Grange DK, van Haaften G, van Bon BW, Hoischen A, Nichols CG. Cantu syndrome resulting from activating mutation in the KCNJ8 gene. Human mutation. 2014; 35(7):809-813. [PubMed: 24700710]

Costa AD. Iptakalim: a new or just another KCO? Cardiovascular research. 2009; 83(3):417-418. [PubMed: 19515796]

Croker B, Crozat K, Berger M, Xia Y, Sovath S, Schaffer L, Eleftherianos I, Imler JL, Beutler B. ATP-sensitive potassium channels mediate survival during infection in mammals and insects. Nature genetics. 2007; 39(12):1453-1460. [PubMed: 18026101]

Cui J, Davidson AL. ABC solute importers in bacteria. Essays in biochemistry. 2011; 50(1):85-99. [PubMed: 21967053]

Czeschik JC, Voigt C, Goecke TO, Ludecke HJ, Wagner N, Kuechler A, Wieczorek D. Wide clinical variability in conditions with coarse facial features and hypertrichosis caused by mutations in ABCC9. Am J Med Genet A. 2013; 161A(2):295-300. [PubMed: 23307537]

Davidson YS, Raby S, Foulds PG, Robinson A, Thompson JC, Sikkink S, Yusuf I, Amin H, DuPlessis D, Troakes C, Al-Sarraj S, Sloan C, Esiri MM, Prasher VP, Allsop D, Neary D, Pickering-Brown SM, Snowden JS, Mann DM. TDP-43 pathological changes in early onset familial and sporadic Alzheimer's disease, late onset Alzheimer's disease and Down's syndrome: association with age, hippocampal sclerosis and clinical phenotype. Acta Neuropathol. 2011; 122(6):703-713. [PubMed: 21968532]

Davis-Taber R, Choi W, Feng J, Hoogenboom L, McNally T, Kroeger P, Shieh CC, Simmer R, Brioni JD, Sullivan JP, Gopalakrishnan M, Scott VE. Molecular characterization of human SUR2containing K(ATP) channels. Gene. 2000; 256(1-2):261-270. [PubMed: 11054556]

Davis FB, Boh DM, Davis PJ, van Son AR, Mylotte KM, Edwards L, Zielezny M, Sczupak C. Factors moderating the effect of oral sulfonylureas on free water clearance. Journal of clinical pharmacology. 1982; 22(2-3):97-101. [PubMed: 7068939]

de Araujo ED, Ikeda LK, Tzvetkova S, Kanelis V. The first nucleotide binding domain of the sulfonylurea receptor $2 \mathrm{~A}$ contains regulatory elements and is folded and functions as an independent module. Biochemistry. 2011; 50(31):6655-6666. [PubMed: 21714514]

de Weille JR, Fosset M, Mourre C, Schmid-Antomarchi H, Bernardi H, Lazdunski M. Pharmacology and regulation of ATP-sensitive K+ channels. Pflugers Archiv : European journal of physiology. 1989; (414 Suppl 1):S80-S87. [PubMed: 2674894]

Deming Y, Cruchaga C. TMEM106B: a strong FTLD disease modifier. Acta Neuropathol. 2014; 127(3):419-422. [PubMed: 24488309]

Dermauw W, Osborne EJ, Clark RM, Grbic M, Tirry L, Van Leeuwen T. A burst of ABC genes in the genome of the polyphagous spider mite Tetranychus urticae. BMC genomics. 2013; 14:317. [PubMed: 23663308]

Dermauw W, Van Leeuwen T. The ABC gene family in arthropods: comparative genomics and role in insecticide transport and resistance. Insect biochemistry and molecular biology. 2014; 45:89-110. [PubMed: 24291285]

Dickson DW, Baker M, Rademakers R. Common variant in GRN is a genetic risk factor for hippocampal sclerosis in the elderly. Neurodegener Dis. 2010; 7(1-3):170-174. [PubMed: 20197700] 
Dickson DW, Davies P, Bevona C, Van Hoeven KH, Factor SM, Grober E, Aronson MK, Crystal HA. Hippocampal sclerosis: a common pathological feature of dementia in very old $(>$ or $=80$ years of age) humans. Acta Neuropathol. 1994; 88(3):212-221. [PubMed: 7810292]

Du Q, Jovanovic S, Tulic L, Sljivancanin D, Jack DW, Zizic V, Abdul KS, Tulic I, Jovanovic A. KATP channels are up-regulated with increasing age in human myometrium. Mechanisms of ageing and development. 2013; 134(3-4):98-102. [PubMed: 23369859]

Duan RF, Cui WY, Wang H. Association of the antihypertensive response of iptakalim with KCNJ11 (Kir6.2 gene) polymorphisms in Chinese Han hypertensive patients. Acta pharmacologica Sinica. 2011; 32(8):1078-1084. [PubMed: 21765448]

Edwards AG, Rees ML, Gioscia RA, Zachman DK, Lynch JM, Browder JC, Chicco AJ, Moore RL. PKC-permitted elevation of sarcolemmal KATP concentration may explain female-specific resistance to myocardial infarction. The Journal of physiology. 2009; 587(Pt 23):5723-5737. [PubMed: 19805744]

Efferth T. Adenosine triphosphate-binding cassette transporter genes in ageing and age-related diseases. Ageing research reviews. 2003; 2(1):11-24. [PubMed: 12437993]

Engels H, Bosse K, Ehrbrecht A, Zahn S, Hoischen A, Propping P, Bindl L, Reutter H. Further case of Cantu syndrome: exclusion of cryptic subtelomeric chromosome aberrations. Am J Med Genet. 2002; 111(2):205-209. [PubMed: 12210352]

Fahrenbach JP, Stoller D, Kim G, Aggarwal N, Yerokun B, Earley JU, Hadhazy M, Shi NQ, Makielski JC, McNally EM. Abcc9 is required for the transition to oxidative metabolism in the newborn heart. FASEB journal : official publication of the Federation of American Societies for Experimental Biology. 2014; 28(7):2804-2815. [PubMed: 24648545]

Farkas E, Luiten PG. Cerebral microvascular pathology in aging and Alzheimer's disease. Prog Neurobiol. 2001; 64(6):575-611. [PubMed: 11311463]

Fatima N, Schooley JF Jr, Claycomb WC, Flagg TP. Promoter DNA methylation regulates murine SUR1 (Abcc8) and SUR2 (Abcc9) expression in HL-1 cardiomyocytes. PloS one. 2012; 7(7):e41533. [PubMed: 22844491]

Flagg TP, Enkvetchakul D, Koster JC, Nichols CG. Muscle KATP channels: recent insights to energy sensing and myoprotection. Physiological reviews. 2010; 90(3):799-829. [PubMed: 20664073]

Flatt PR, Shibier O, Szecowka J, Berggren PO. New perspectives on the actions of sulphonylureas and hyperglycaemic sulphonamides on the pancreatic beta-cell. Diabete \& metabolisme. 1994; 20(2): 157-162. [PubMed: 7805953]

Florez JC, Burtt N, de Bakker PI, Almgren P, Tuomi T, Holmkvist J, Gaudet D, Hudson TJ, Schaffner SF, Daly MJ, Hirschhorn JN, Groop L, Altshuler D. Haplotype structure and genotype-phenotype correlations of the sulfonylurea receptor and the islet ATP-sensitive potassium channel gene region. Diabetes. 2004; 53(5):1360-1368. [PubMed: 15111507]

Fogal B, McClaskey C, Yan S, Yan H, Rivkees SA. Diazoxide promotes oligodendrocyte precursor cell proliferation and myelination. PloS one. 2010; 5(5):e10906. [PubMed: 20531945]

Frey G, Lucht M, Schlue WR. ATP-inhibited K+ channels and membrane potential of identified leech neurons. Brain Res. 1998; 798(1-2):247-253. [PubMed: 9666141]

Furney SJ, Simmons A, Breen G, Pedroso I, Lunnon K, Proitsi P, Hodges A, Powell J, Wahlund LO, Kloszewska I, Mecocci P, Soininen H, Tsolaki M, Vellas B, Spenger C, Lathrop M, Shen L, Kim S, Saykin AJ, Weiner MW, Lovestone S, Alzheimer's Disease Neuroimaging I, AddNeuroMed C. Genome-wide association with MRI atrophy measures as a quantitative trait locus for Alzheimer's disease. Mol Psychiatry. 2011; 16(11):1130-1138. [PubMed: 21116278]

Gade AR, Kang M, Akbarali HI. Hydrogen sulfide as an allosteric modulator of ATP-sensitive potassium channels in colonic inflammation. Molecular pharmacology. 2013; 83(1):294-306. [PubMed: 23115325]

Gao J, Xu D, Sabat G, Valdivia H, Xu W, Shi NQ. Disrupting KATP channels diminishes the estrogen-mediated protection in female mutant mice during ischemia-reperfusion. Clinical proteomics. 2014; 11(1):19. [PubMed: 24936167]

Gao M, Xue H, Wang Y, Wang H. Iptakalim, opener of K(ATP), reverses the enhanced expression of genes encoding K(ATP) subunits in spontaneously hypertensive rats. Life sciences. 2005; 77(22): 2743-2751. [PubMed: 15964031] 
Garcia-Cruz D, Sanchez-Corona J, Nazara Z, Garcia-Cruz MO, Figuera LE, Castaneda V, Cantu JM. Congenital hypertrichosis, osteochondrodysplasia, and cardiomegaly: further delineation of a new genetic syndrome. Am J Med Genet. 1997; 69(2):138-151. [PubMed: 9056550]

Garcia-Gonzalez CL, Garcia-Cruz D, Garcia-Cruz MO, Castaneda-Cisneros G, Garcia-Ortiz JE, Orozco-Gutierrez MH, Sanchez-Corona J. A familial case of Cantu craniofaciofronto digital syndrome. Clinical dysmorphology. 2012; 21(3):162-166. [PubMed: 22504422]

Giblin JP, Cui Y, Clapp LH, Tinker A. Assembly limits the pharmacological complexity of ATPsensitive potassium channels. J Biol Chem. 2002; 277(16):13717-13723. [PubMed: 11825905]

Gloyn AL, Weedon MN, Owen KR, Turner MJ, Knight BA, Hitman G, Walker M, Levy JC, Sampson M, Halford S, McCarthy MI, Hattersley AT, Frayling TM. Large-scale association studies of variants in genes encoding the pancreatic beta-cell KATP channel subunits Kir6.2 (KCNJ11) and SUR1 (ABCC8) confirm that the KCNJ11 E23K variant is associated with type 2 diabetes. Diabetes. 2003; 52(2):568-572. [PubMed: 12540637]

Goodman Y, Mattson MP. K+ channel openers protect hippocampal neurons against oxidative injury and amyloid beta-peptide toxicity. Brain Res. 1996; 706(2):328-332. [PubMed: 8822377]

Grange DK, Lorch SM, Cole PL, Singh GK. Cantu syndrome in a woman and her two daughters: Further confirmation of autosomal dominant inheritance and review of the cardiac manifestations. American journal of medical genetics Part A. 2006; 140(15):1673-1680. [PubMed: 16835932]

Grange, DK.; Nichols, CG.; Singh, GK. Cantu Syndrome and Related Disorders. Pagon, RA.; Adam, MP.; Ardinger, HH.; Bird, TD.; Dolan, CR.; Fong, CT.; Smith, RJH.; Stephens, K., editors. Seattle (WA): GeneReviews(R); 2014.

Graziadio C, Rosa RF, Rosa RC, Zen PR, Flores JA, Paskulin GA. Short-term follow-up of a Brazilian patient with Cantu syndrome. American journal of medical genetics Part A. 2011; 155A(5):11841188. [PubMed: 21465652]

Haghverdizadeh P, Sadat Haerian M, Haghverdizadeh P, Sadat Haerian B. ABCC8 genetic variants and risk of diabetes mellitus. Gene. 2014; 545(2):198-204. [PubMed: 24768178]

Hamel E. The Cerebral Circulation: Function and Dysfunction in Alzheimer's disease. Journal of cardiovascular pharmacology. 2014

Harakalova M, van Harssel JJ, Terhal PA, van Lieshout S, Duran K, Renkens I, Amor DJ, Wilson LC, Kirk EP, Turner CL, Shears D, Garcia-Minaur S, Lees MM, Ross A, Venselaar H, Vriend G, Takanari H, Rook MB, van der Heyden MA, Asselbergs FW, Breur HM, Swinkels ME, Scurr IJ, Smithson SF, Knoers NV, van der Smagt JJ, Nijman IJ, Kloosterman WP, van Haelst MM, van Haaften G, Cuppen E. Dominant missense mutations in ABCC9 cause Cantu syndrome. Nature genetics. 2012; 44(7):793-796. [PubMed: 22610116]

Haug E, Oie M, Andreassen OA, Bratlien U, Nelson B, Aas M, Moller P, Melle I. Anomalous selfexperience and childhood trauma in first-episode schizophrenia. Comprehensive psychiatry. 2015; 56:35-41. [PubMed: 25458477]

Heurteaux C, Bertaina V, Widmann C, Lazdunski M. K+ channel openers prevent global ischemiainduced expression of c-fos, c-jun, heat shock protein, and amyloid beta-protein precursor genes and neuronal death in rat hippocampus. Proc Natl Acad Sci U S A. 1993; 90(20):9431-9435. [PubMed: 8415718]

Hicks GA, Hudson AL, Henderson G. Localization of high affinity [3H]glibenclamide binding sites within the substantia nigra zona reticulata of the rat brain. Neuroscience. 1994; 61(2):285-292. [PubMed: 7969909]

Hiraki Y, Miyatake S, Hayashidani M, Nishimura Y, Matsuura H, Kamada M, Kawagoe T, Yunoki K, Okamoto N, Yofune H, Nakashima M, Tsurusaki Y, Satisu H, Murakami A, Miyake N, Nishimura G, Matsumoto N. Aortic aneurysm and craniosynostosis in a family with Cantu syndrome. American journal of medical genetics Part A. 2014; 164A(1):231-236. [PubMed: 24352916]

Hu D, Barajas-Martinez H, Terzic A, Park S, Pfeiffer R, Burashnikov E, Wu Y, Borggrefe M, Veltmann C, Schimpf R, Cai JJ, Nam GB, Deshmukh P, Scheinman M, Preminger M, Steinberg J, Lopez-Izquierdo A, Ponce-Balbuena D, Wolpert C, Haissaguerre M, Sanchez-Chapula JA, Antzelevitch C. ABCC9 is a novel Brugada and early repolarization syndrome susceptibility gene. International journal of cardiology. 2014; 171(3):431-442. [PubMed: 24439875] 
Hu LF, Wang S, Shi XR, Yao HH, Sun YH, Ding JH, Liu SY, Hu G. ATP-sensitive potassium channel opener iptakalim protected against the cytotoxicity of MPP+ on SH-SY5Y cells by decreasing extracellular glutamate level. J Neurochem. 2005; 94(6):1570-1579. [PubMed: 16000145]

Hunter JM, Kwan J, Malek-Ahmadi M, Maarouf CL, Kokjohn TA, Belden C, Sabbagh MN, Beach TG, Roher AE. Morphological and pathological evolution of the brain microcirculation in aging and Alzheimer's disease. PloS one. 2012; 7(5):e36893. [PubMed: 22615835]

Igarashi Y, Aoki KF, Mamitsuka H, Kuma K, Kanehisa M. The evolutionary repertoires of the eukaryotic-type ABC transporters in terms of the phylogeny of ATP-binding domains in eukaryotes and prokaryotes. Molecular biology and evolution. 2004; 21(11):2149-2160. [PubMed: 15297601]

Inagaki N, Gonoi T, Clement JP, Wang CZ, Aguilar-Bryan L, Bryan J, Seino S. A family of sulfonylurea receptors determines the pharmacological properties of ATP-sensitive $\mathrm{K}+$ channels. Neuron. 1996; 16(5):1011-1017. [PubMed: 8630239]

Inoue H, Ferrer J, Warren-Perry M, Zhang Y, Millns H, Turner RC, Elbein SC, Hampe CL, Suarez BK, Inagaki N, Seino S, Permutt MA. Sequence variants in the pancreatic islet beta-cell inwardly rectifying $\mathrm{K}+$ channel Kir6.2 (Bir) gene: identification and lack of role in Caucasian patients with NIDDM. Diabetes. 1997; 46(3):502-507. [PubMed: 9032109]

Isomoto S, Kondo C, Yamada M, Matsumoto S, Higashiguchi O, Horio Y, Matsuzawa Y, Kurachi Y. A novel sulfonylurea receptor forms with BIR (Kir6.2) a smooth muscle type ATP-sensitive K+ channel. J Biol Chem. 1996; 271(40):24321-24324. [PubMed: 8798681]

Isomoto S, Kurachi Y. Function, regulation, pharmacology, and molecular structure of ATP-sensitive $\mathrm{K}+$ channels in the cardiovascular system. Journal of cardiovascular electrophysiology. 1997; 8(12):1431-1446. [PubMed: 9436781]

Jackson JE, Bressler R. Clinical pharmacology of sulphonylurea hypoglycaemic agents: part 1. Drugs. 1981a; 22(3):211-245. [PubMed: 7021124]

Jackson JE, Bressler R. Clinical pharmacology of sulphonylurea hypoglycaemic agents: part 2. Drugs. 1981b; 22(4):295-320. [PubMed: 7030708]

Jansen-Olesen I, Mortensen CH, El-Bariaki N, Ploug KB. Characterization of K(ATP)-channels in rat basilar and middle cerebral arteries: studies of vasomotor responses and mRNA expression. European journal of pharmacology. 2005; 523(1-3):109-118. [PubMed: 16226739]

Jiang K, Yu Z, Shui Q. The pattern of ATP-sensitive K+ channel subunits, Kir6.2 and SUR1 mRNA expressions in DG region is different from those in CA1-3 regions of chronic epilepsy induced by picrotoxin in rats. Neuropathology. 2007; 27(6):531-538. [PubMed: 18021373]

Kalaria RN, Akinyemi R, Ihara M. Does vascular pathology contribute to Alzheimer changes? J Neurol Sci. 2012; 322(1-2):141-147. [PubMed: 22884479]

Kamide K, Asayama K, Katsuya T, Ohkubo T, Hirose T, Inoue R, Metoki H, Kikuya M, Obara T, Hanada H, Thijs L, Kuznetsova T, Noguchi Y, Sugimoto K, Ohishi M, Morimoto S, Nakahashi T, Takiuchi S, Ishimitsu T, Tsuchihashi T, Soma M, Higaki J, Matsuura H, Shinagawa T, Sasaguri T, Miki T, Takeda K, Shimamoto K, Ueno M, Hosomi N, Kato J, Komai N, Kojima S, Sase K, Miyata T, Tomoike H, Kawano Y, Ogihara T, Rakugi H, Staessen JA, Imai Y, group Gs, group HB.s. Genome-wide response to antihypertensive medication using home blood pressure measurements: a pilot study nested within the HOMED-BP study. Pharmacogenomics. 2013; 14(14):1709-1721. [PubMed: 24192120]

Kane GC, Liu XK, Yamada S, Olson TM, Terzic A. Cardiac KATP channels in health and disease. Journal of molecular and cellular cardiology. 2005; 38(6):937-943. [PubMed: 15910878]

Kang M, Hashimoto A, Gade AR, Akbarali HI. Interaction between hydrogen sulfide-induced sulfhydration and tyrosine nitration in the KATP channel complex. American journal of physiology Gastrointestinal and liver physiology, ajpgi. 2014; 00281

Kawano T, Tanaka K, Chi H, Kimura M, Kawano H, Eguchi S, Oshita S. Effects of aging on isoflurane-induced and protein kinase A-mediated activation of ATP-sensitive potassium channels in cultured rat aortic vascular smooth muscle cells. Journal of cardiovascular pharmacology. 2010; 56(6):676-685. [PubMed: 20881605] 
Kim JH, Cheong HS, Sul JH, Seo JM, Kim DY, Oh JT, Park KW, Kim HY, Jung SM, Jung K, Cho MJ, Bae JS, Shin HD. A genome-wide association study identifies potential susceptibility loci for Hirschsprung disease. PloS one. 2014; 9(10):e110292. [PubMed: 25310821]

Kirsch T, Wellner M, Luft FC, Haller H, Lippoldt A. Altered gene expression in cerebral capillaries of stroke-prone spontaneously hypertensive rats. Brain Res. 2001; 910(1-2):106-115. [PubMed: 11489260]

Ko EA, Han J, Jung ID, Park WS. Physiological roles of K+ channels in vascular smooth muscle cells. Journal of smooth muscle research = Nihon Heikatsukin Gakkai kikanshi. 2008; 44(2):65-81. [PubMed: 18552454]

Kobayashi D, Cook AL, Williams DA. Pulmonary hypertension secondary to partial pulmonary venous obstruction in a child with Cantu syndrome. Pediatr Pulmonol. 2010; 45(7):727-729. [PubMed: 20575102]

Kong M, Ba M. Protective effects of diazoxide against Abeta(2)(5)(-)(3)(5)-induced PC12 cell apoptosis due to prevention of endoplasmic reticulum stress. Neuroreport. 2012; 23(8):493-497. [PubMed: 22551949]

Koster JC, Kurata HT, Enkvetchakul D, Nichols CG. DEND mutation in Kir6.2 (KCNJ11) reveals a flexible N-terminal region critical for ATP-sensing of the KATP channel. Biophysical journal. 2008; 95(10):4689-4697. [PubMed: 18708460]

Kuslansky G, Verghese J, Dickson D, Katz M, Busche H, Lipton RB. Hippocampal sclerosis: cognitive consequences and contribution to dementia. Neurology. 2004; 62:A128-A129.

Lacza Z, Snipes JA, Kis B, Szabo C, Grover G, Busija DW. Investigation of the subunit composition and the pharmacology of the mitochondrial ATP-dependent $\mathrm{K}+$ channel in the brain. Brain Res. 2003; 994(1):27-36. [PubMed: 14642445]

Laukkanen O, Pihlajamaki J, Lindstrom J, Eriksson J, Valle TT, Hamalainen H, Ilanne-Parikka P, Keinanen-Kiukaanniemi S, Tuomilehto J, Uusitupa M, Laakso M, Finnish Diabetes Prevention Study G. Polymorphisms of the SUR1 (ABCC8) and Kir6.2 (KCNJ11) genes predict the conversion from impaired glucose tolerance to type 2 diabetes. The Finnish Diabetes Prevention Study. The Journal of clinical endocrinology and metabolism. 2004; 89(12):6286-6290. [PubMed: 15579791]

Lazalde B, Sanchez-Urbina R, Nuno-Arana I, Bitar WE, de Lourdes Ramirez-Duenas M. Autosomal dominant inheritance in Cantu syndrome (congenital hypertrichosis, osteochondrodysplasia, and cardiomegaly). Am J Med Genet. 2000; 94(5):421-427. [PubMed: 11050630]

Lee CR, Witkovsky P, Rice ME. Regulation of Substantia Nigra Pars Reticulata GABAergic Neuron Activity by $\mathrm{H}(2) \mathrm{O}(2)$ via Flufenamic Acid-Sensitive Channels and K(ATP) Channels. Frontiers in systems neuroscience. 2011; 5:14. [PubMed: 21503158]

Lee EB, Lee VM, Trojanowski JQ, Neumann M. TDP-43 immunoreactivity in anoxic, ischemic and neoplastic lesions of the central nervous system. Acta Neuropathol. 2008; 115(3):305-311. [PubMed: 18087705]

Leverenz JB, Lipton AM. Clinical aspects of hippocampal sclerosis. Handb Clin Neurol. 2008; 89:565-567. [PubMed: 18631778]

Li A, Knutsen RH, Zhang H, Osei-Owusu P, Moreno-Dominguez A, Harter TM, Uchida K, Remedi MS, Dietrich HH, Bernal-Mizrachi C, Blumer KJ, Mecham RP, Koster JC, Nichols CG. Hypotension due to Kir6.1 gain-of-function in vascular smooth muscle. Journal of the American Heart Association. 2013; 2(4):e000365. [PubMed: 23974906]

Liang GH, Adebiyi A, Leo MD, McNally EM, Leffler CW, Jaggar JH. Hydrogen sulfide dilates cerebral arterioles by activating smooth muscle cell plasma membrane KATP channels. American journal of physiology Heart and circulatory physiology. 2011; 300(6):H2088-H2095. [PubMed: 21421823]

Light P. Regulation of ATP-sensitive potassium channels by phosphorylation. Biochimica et biophysica acta. 1996; 1286(1):65-73. [PubMed: 8634324]

Lindauer U, Vogt J, Schuh-Hofer S, Dreier JP, Dirnagl U. Cerebrovascular vasodilation to extraluminal acidosis occurs via combined activation of ATP-sensitive and Ca2+-activated potassium channels. J Cereb Blood Flow Metab. 2003; 23(10):1227-1238. [PubMed: 14526233] 
Ling H, Holton JL, Lees AJ, Revesz T. TDP-43 pathology is present in most post-encephalitic parkinsonism brains. Neuropathol Appl Neurobiol. 2013

Liss B, Bruns R, Roeper J. Alternative sulfonylurea receptor expression defines metabolic sensitivity of K-ATP channels in dopaminergic midbrain neurons. EMBO J. 1999; 18(4):833-846. [PubMed: 10022826]

Littleton JT, Ganetzky B. Ion channels and synaptic organization: analysis of the Drosophila genome. Neuron. 2000; 26(1):35-43. [PubMed: 10798390]

Liu D, Lu C, Wan R, Auyeung WW, Mattson MP. Activation of mitochondrial ATP-dependent potassium channels protects neurons against ischemia-induced death by a mechanism involving suppression of Bax translocation and cytochrome c release. J Cereb Blood Flow Metab. 2002; 22(4):431-443. [PubMed: 11919514]

Liu D, Pitta M, Lee JH, Ray B, Lahiri DK, Furukawa K, Mughal M, Jiang H, Villarreal J, Cutler RG, Greig NH, Mattson MP. The KATP channel activator diazoxide ameliorates amyloid-beta and tau pathologies and improves memory in the 3xTgAD mouse model of Alzheimer's disease. J Alzheimers Dis. 2010; 22(2):443-457. [PubMed: 20847430]

Liu D, Slevin JR, Lu C, Chan SL, Hansson M, Elmer E, Mattson MP. Involvement of mitochondrial K + release and cellular efflux in ischemic and apoptotic neuronal death. J Neurochem. 2003; 86(4): 966-979. [PubMed: 12887694]

Liu Y, Ren G, O'Rourke B, Marban E, Seharaseyon J. Pharmacological comparison of native mitochondrial K(ATP) channels with molecularly defined surface K(ATP) channels. Molecular pharmacology. 2001; 59(2):225-230. [PubMed: 11160857]

Lodwick D, Rainbow RD, Rubaiy HN, Al Johi M, Vuister GW, Norman RI. Sulfonylurea receptors regulate the channel pore in ATP-sensitive potassium channels via an intersubunit salt bridge. The Biochemical journal. 2014; 464(3):343-354. [PubMed: 25236767]

Lu M, Yang JZ, Geng F, Ding JH, Hu G. Iptakalim confers an antidepressant effect in a chronic mild stress model of depression through regulating neuro-inflammation and neurogenesis. The international journal of neuropsychopharmacology / official scientific journal of the Collegium Internationale Neuropsychopharmacologicum. 2014; 17(9):1501-1510.

Ma G, Fu Q, Zhang Y, Gao J, Jiang J, Bi A, Liu K, Du Y, Chen C, Cui Y, Lu L. Effects of Abeta1-42 on the subunits of KATP expression in cultured primary rat basal forebrain neurons. Neurochem Res. 2008; 33(7):1419-1424. [PubMed: 18335313]

Ma G, Gao J, Fu Q, Jiang L, Wang R, Zhang Y, Liu K. Diazoxide reverses the enhanced expression of KATP subunits in cholinergic neurons caused by exposure to Abeta(1)(-)(4)(2). Neurochem Res. 2009; 34(12):2133-2140. [PubMed: 19488853]

Maack C, Dabew ER, Hohl M, Schafers HJ, Bohm M. Endogenous activation of mitochondrial KATP channels protects human failing myocardium from hydroxyl radical-induced stunning. Circulation research. 2009; 105(8):811-817. [PubMed: 19729596]

Macauley SL, Stanley M, Caesar EE, Yamada SA, Raichle ME, Perez R, Mahan TE, Sutphen CL, Holtzman DM. Hyperglycemia modulates extracellular amyloid-beta concentrations and neuronal activity in vivo. The Journal of clinical investigation. 2015; 125(6):2463-2467. [PubMed: 25938784]

MacCormack TJ, Driedzic WR. Mitochondrial ATP-sensitive K+ channels influence force development and anoxic contractility in a flatfish, yellowtail flounder Limanda ferruginea, but not Atlantic cod Gadus morhua heart. The Journal of experimental biology. 2002; 205(Pt 10): 1411-1418. [PubMed: 11976352]

McKee AC, Gavett BE, Stern RA, Nowinski CJ, Cantu RC, Kowall NW, Perl DP, Hedley-Whyte ET, Price B, Sullivan C, Morin P, Lee HS, Kubilus CA, Daneshvar DH, Wulff M, Budson AE. TDP-43 proteinopathy and motor neuron disease in chronic traumatic encephalopathy. Journal of neuropathology and experimental neurology. 2010; 69(9):918-929. [PubMed: 20720505]

Mehta RI, Ivanova S, Tosun C, Castellani RJ, Gerzanich V, Simard JM. Sulfonylurea receptor 1 expression in human cerebral infarcts. Journal of neuropathology and experimental neurology. 2013; 72(9):871-883. [PubMed: 23965746] 
Melander A, Bitzen PO, Faber O, Groop L. Sulphonylurea antidiabetic drugs. An update of their clinical pharmacology and rational therapeutic use. Drugs. 1989; 37(1):58-72. [PubMed: 2651086]

Miki T, Suzuki M, Shibasaki T, Uemura H, Sato T, Yamaguchi K, Koseki H, Iwanaga T, Nakaya H, Seino S. Mouse model of Prinzmetal angina by disruption of the inward rectifier Kir6.1. Nature medicine. 2002; 8(5):466-472.

Minami K, Miki T, Kadowaki T, Seino S. Roles of ATP-sensitive K+ channels as metabolic sensors: studies of Kir6.x null mice. Diabetes. 2004; (53 Suppl 3):S176-S180. [PubMed: 15561908]

Minoretti P, Falcone C, Aldeghi A, Olivieri V, Mori F, Emanuele E, Calcagnino M, Geroldi D. A novel Val734Ile variant in the ABCC9 gene associated with myocardial infarction. Clinica chimica acta; international journal of clinical chemistry. 2006; 370(1-2):124-128.

Miralles MJ, McGinty JW, Martin A. Combined water-soluble carriers for coprecipitates of tolbutamide. Journal of pharmaceutical sciences. 1982; 71(3):302-304. [PubMed: 7069585]

Misler S, Giebisch G. ATP-sensitive potassium channels in physiology, pathophysiology, and pharmacology. Current opinion in nephrology and hypertension. 1992; 1(1):21-33. [PubMed: 1365828]

Montagne A, Barnes SR, Sweeney MD, Halliday MR, Sagare AP, Zhao Z, Toga AW, Jacobs RE, Liu CY, Amezcua L, Harrington MG, Chui HC, Law M, Zlokovic BV. Blood-brain barrier breakdown in the aging human hippocampus. Neuron. 2015; 85(2):296-302. [PubMed: 25611508]

Montine TJ, Koroshetz WJ, Babcock D, Dickson DW, Galpern WR, Glymour MM, Greenberg SM, Hutton ML, Knopman DS, Kuzmichev AN, Manly JJ, Marder KS, Miller BL, Phelps CH, Seeley WW, Sieber BA, Silverberg NB, Sutherland M, Torborg CL, Waddy SP, Zlokovic BV, Corriveau RA, Committee ACO. Recommendations of the Alzheimer's disease-related dementias conference. Neurology. 2014; 83(9):851-860. [PubMed: 25080517]

Montine TJ, Phelps CH, Beach TG, Bigio EH, Cairns NJ, Dickson DW, Duyckaerts C, Frosch MP, Masliah E, Mirra SS, Nelson PT, Schneider JA, Thal DR, Trojanowski JQ, Vinters HV, Hyman BT, National Institute on A, Alzheimer's A. National Institute on Aging-Alzheimer's Association guidelines for the neuropathologic assessment of Alzheimer's disease: a practical approach. Acta Neuropathol. 2012; 123(1):1-11. [PubMed: 22101365]

Murray ME, Cannon A, Graff-Radford NR, Liesinger AM, Rutherford NJ, Ross OA, Duara R, Carrasquillo MM, Rademakers R, Dickson DW. Differential clinicopathologic and genetic features of late-onset amnestic dementias. Acta Neuropathol. 2014

Nag S, Yu L, Capuano AW, Wilson RS, Leurgans SE, Bennett DA, Schneider JA. Hippocampal sclerosis and TDP-43 pathology in aging and Alzheimer's Disease. Ann Neurol. 2015

Nasonkin I, Alikasifoglu A, Ambrose C, Cahill P, Cheng M, Sarniak A, Egan M, Thomas PM. A novel sulfonylurea receptor family member expressed in the embryonic Drosophila dorsal vessel and tracheal system. J Biol Chem. 1999; 274(41):29420-29425. [PubMed: 10506204]

Nelson PT, Abner EL, Schmitt FA, Kryscio RJ, Jicha GA, Smith CD, Davis DG, Poduska JW, Patel E, Mendiondo MS, Markesbery WR. Modeling the association between 43 different clinical and pathological variables and the severity of cognitive impairment in a large autopsy cohort of elderly persons. Brain Pathol. 2010; 20(1):66-79. [PubMed: 19021630]

Nelson PT, Estus S, Abner EL, Parikh I, Malik M, Neltner JH, Ighodaro E, Wang WX, Wilfred BR, Wang LS, Kukull WA, Nandakumar K, Farman ML, Poon WW, Corrada MM, Kawas CH, Cribbs DH, Bennett DA, Schneider JA, Larson EB, Crane PK, Valladares O, Schmitt FA, Kryscio RJ, Jicha GA, Smith CD, Scheff SW, Sonnen JA, Haines JL, Pericak-Vance MA, Mayeux R, Farrer LA, Van Eldik LJ, Horbinski C, Green RC, Gearing M, Poon LW, Kramer PL, Woltjer RL, Montine TJ, Partch AB, Rajic AJ, Richmire K, Monsell SE, Alzheimer' Disease Genetic C, Schellenberg GD, Fardo DW. ABCC9 gene polymorphism is associated with hippocampal sclerosis of aging pathology. Acta Neuropathol. 2014; 127(6):825-843. [PubMed: 24770881]

Nelson PT, Keller JN. RNA in brain disease: no longer just "the messenger in the middle". Journal of neuropathology and experimental neurology. 2007; 66(6):461-468. [PubMed: 17549006]

Nelson PT, Schmitt FA, Lin Y, Abner EL, Jicha GA, Patel E, Thomason PC, Neltner JH, Smith CD, Santacruz KS, Sonnen JA, Poon LW, Gearing M, Green RC, Woodard JL, Van Eldik LJ, Kryscio 
RJ. Hippocampal sclerosis in advanced age: clinical and pathological features. Brain. 2011; 134(Pt 5):1506-1518. [PubMed: 21596774]

Nelson PT, Smith CD, Abner EL, Wilfred BJ, Wang WX, Neltner JH, Baker M, Fardo DW, Kryscio RJ, Scheff SW, Jicha GA, Jellinger KA, Van Eldik LJ, Schmitt FA. Hippocampal sclerosis of aging, a prevalent and high-morbidity brain disease. Acta Neuropathol. 2013; 126(2):161-177. [PubMed: 23864344]

Nelson PT, Wang WX, Partch AB, Monsell SE, Valladares O, Ellingson SR, Wilfred BR, Naj AC, Wang LS, Kukull WA, Fardo DW. Reassessment of risk genotypes (GRN, TMEM106B, and ABCC9 variants) associated with hippocampal sclerosis of aging pathology. Journal of neuropathology and experimental neurology. 2015; 74(1):75-84. [PubMed: 25470345]

Neltner JH, Abner EL, Baker S, Schmitt FA, Kryscio RJ, Jicha GA, Smith CD, Hammack E, Kukull WA, Brenowitz WD, Van Eldik LJ, Nelson PT. Arteriolosclerosis that affects multiple brain regions is linked to hippocampal sclerosis of ageing. Brain. 2014; 137(Pt 1):255-267. [PubMed: 24271328]

Neumann M, Sampathu DM, Kwong LK, Truax AC, Micsenyi MC, Chou TT, Bruce J, Schuck T, Grossman M, Clark CM, McCluskey LF, Miller BL, Masliah E, Mackenzie IR, Feldman H, Feiden W, Kretzschmar HA, Trojanowski JQ, Lee VM. Ubiquitinated TDP-43 in frontotemporal lobar degeneration and amyotrophic lateral sclerosis. Science. 2006; 314(5796):130-133. [PubMed: 17023659]

Nevin NC, Mulholland HC, Thomas PS. Congenital hypertrichosis, cardiomegaly and mild osteochondrodysplasia. Am J Med Genet. 1996; 66(1):33-38. [PubMed: 8957508]

Nichols CG. KATP channels as molecular sensors of cellular metabolism. Nature. 2006; 440(7083): 470-476. [PubMed: 16554807]

Nichols CG, Singh GK, Grange DK. KATP channels and cardiovascular disease: suddenly a syndrome. Circulation research. 2013; 112(7):1059-1072. [PubMed: 23538276]

Nielsen EM, Hansen L, Carstensen B, Echwald SM, Drivsholm T, Glumer C, Thorsteinsson B, BorchJohnsen K, Hansen T, Pedersen O. The E23K variant of Kir6.2 associates with impaired postOGTT serum insulin response and increased risk of type 2 diabetes. Diabetes. 2003; 52(2):573577. [PubMed: 12540638]

Nishimura M, Ocorr K, Bodmer R, Cartry J. Drosophila as a model to study cardiac aging. Exp Gerontol. 2011; 46(5):326-330. [PubMed: 21130861]

Ocorr K, Perrin L, Lim HY, Qian L, Wu X, Bodmer R. Genetic control of heart function and aging in Drosophila. Trends in cardiovascular medicine. 2007; 17(5):177-1782. [PubMed: 17574126]

Olson TM, Alekseev AE, Moreau C, Liu XK, Zingman LV, Miki T, Seino S, Asirvatham SJ, Jahangir A, Terzic A. KATP channel mutation confers risk for vein of Marshall adrenergic atrial fibrillation. Nature clinical practice Cardiovascular medicine. 2007; 4(2):110-116.

Olson TM, Terzic A. Human K(ATP) channelopathies: diseases of metabolic homeostasis. Pflugers Archiv : European journal of physiology. 2010; 460(2):295-306. [PubMed: 20033705]

Ortega FJ, Gimeno-Bayon J, Espinosa-Parrilla JF, Carrasco JL, Batlle M, Pugliese M, Mahy N, Rodriguez MJ. ATP-dependent potassium channel blockade strengthens microglial neuroprotection after hypoxia-ischemia in rats. Exp Neurol. 2012; 235(1):282-296. [PubMed: 22387180]

Pao WC, Dickson DW, Crook JE, Finch NA, Rademakers R, Graff-Radford NR. Hippocampal sclerosis in the elderly: genetic and pathologic findings, some mimicking Alzheimer disease clinically. Alzheimer disease and associated disorders. 2011; 25(4):364-368. [PubMed: 21346515]

Park JY, Koo SH, Jung YJ, Lim YJ, Chung ML. A patient with Cantu syndrome associated with fatal bronchopulmonary dysplasia and pulmonary hypertension. American journal of medical genetics Part A. 2014; 164A(8):2118-2120. [PubMed: 24715715]

Park S, Lim BB, Perez-Terzic C, Mer G, Terzic A. Interaction of asymmetric ABCC9-encoded nucleotide binding domains determines KATP channel SUR2A catalytic activity. Journal of proteome research. 2008; 7(4):1721-1728. [PubMed: 18311911] 
Park S, Terzic A. Quaternary structure of KATP channel SUR2A nucleotide binding domains resolved by synchrotron radiation X-ray scattering. Journal of structural biology. 2010; 169(2):243-251. [PubMed: 19919849]

Parsons MJ, Lester KJ, Barclay NL, Nolan PM, Eley TC, Gregory AM. Replication of Genome-Wide Association Studies (GWAS) loci for sleep in the British G1219 cohort. American journal of medical genetics Part B, Neuropsychiatric genetics : the official publication of the International Society of Psychiatric Genetics. 2013; 162B(5):431-438.

Ploug KB, Baun M, Hay-Schmidt A, Olesen J, Jansen-Olesen I. Presence and vascular pharmacology of KATP channel subtypes in rat central and peripheral tissues. European journal of pharmacology. 2010; 637(1-3):109-117. [PubMed: 20361954]

Ploug KB, Edvinsson L, Olesen J, Jansen-Olesen I. Pharmacological and molecular comparison of $\mathrm{K}(\mathrm{ATP})$ channels in rat basilar and middle cerebral arteries. European journal of pharmacology. 2006; 553(1-3):254-262. [PubMed: 17101127]

Ploug KB, Sorensen MA, Strobech L, Klaerke DA, Hay-Schmidt A, Sheykhzade M, Olesen J, JansenOlesen I. K ATP channels in pig and human intracranial arteries. European journal of pharmacology. 2008; 601(1-3):43-49. [PubMed: 18996111]

Rademakers R, Eriksen JL, Baker M, Robinson T, Ahmed Z, Lincoln SJ, Finch N, Rutherford NJ, Crook RJ, Josephs KA, Boeve BF, Knopman DS, Petersen RC, Parisi JE, Caselli RJ, Wszolek ZK, Uitti RJ, Feldman H, Hutton ML, Mackenzie IR, Graff-Radford NR, Dickson DW. Common variation in the miR-659 binding-site of GRN is a major risk factor for TDP43-positive frontotemporal dementia. Hum Mol Genet. 2008; 17(23):3631-3642. [PubMed: 18723524]

Rana A, Goyal N, Ahlawat A, Jamwal S, Reddy B, Sharma S. Mechanisms involved in attenuated cardio-protective role of ischemic preconditioning in metabolic disorders. Perfusion. 2015; 30(2): 94-105. [PubMed: 24947460]

Reed BR, Mungas DM, Kramer JH, Ellis W, Vinters HV, Zarow C, Jagust WJ, Chui HC. Profiles of neuropsychological impairment in autopsy-defined Alzheimer's disease and cerebrovascular disease. Brain. 2007; 130(Pt 3):731-739. [PubMed: 17267522]

Remedi MS, Nichols CG. Hyperinsulinism and diabetes: genetic dissection of beta cell metabolismexcitation coupling in mice. Cell metabolism. 2009; 10(6):442-453. [PubMed: 19945402]

Riordan JR, Rommens JM, Kerem B, Alon N, Rozmahel R, Grzelczak Z, Zielenski J, Lok S, Plavsic $\mathrm{N}$, Chou JL, et al. Identification of the cystic fibrosis gene: cloning and characterization of complementary DNA. Science. 1989; 245(4922):1066-1073. [PubMed: 2475911]

Robertson SP, Kirk E, Bernier F, Brereton J, Turner A, Bankier A. Congenital hypertrichosis, osteochondrodysplasia, and cardiomegaly: Cantu syndrome. Am J Med Genet. 1999; 85(4):395402. [PubMed: 10398267]

Rosser EM, Kaariainen H, Hurst JA, Baraitser M, Hall CM, Clayton P, Leonard JV. Three patients with the osteochondrodysplasia and hypertrichosis syndrome--Cantu syndrome. Clinical dysmorphology. 1998; 7(2):79-85. [PubMed: 9571276]

Sagare AP, Bell RD, Zhao Z, Ma Q, Winkler EA, Ramanathan A, Zlokovic BV. Pericyte loss influences Alzheimer-like neurodegeneration in mice. Nature communications. 2013; 4:2932.

Salgado D, Shek EW, Alkadhi KA. Effects of ATP-sensitive K(+)-channel activators on transmitter release parameters at the frog neuromuscular junction. Brain Res. 1993; 609(1-2):307-312. [PubMed: 8099524]

Sanada S, Kitakaze M. Ischemic preconditioning: emerging evidence, controversy, and translational trials. International journal of cardiology. 2004; 97(2):263-276. [PubMed: 15458694]

Sato N, Nakayama T, Asai S, Soma M. A haplotype in the human Sur2 gene is associated with essential hypertension. Journal of human hypertension. 2006; 20(1):87-90. [PubMed: 16267564]

Scurr I, Wilson L, Lees M, Robertson S, Kirk E, Turner A, Morton J, Kidd A, Shashi V, Stanley C, Berry M, Irvine AD, Goudie D, Turner C, Brewer C, Smithson S. Cantu syndrome: report of nine new cases and expansion of the clinical phenotype. American journal of medical genetics Part A. 2011; 155A(3):508-518. [PubMed: 21344641]

Seino S, Iwanaga T, Nagashima K, Miki T. Diverse roles of K(ATP) channels learned from Kir6.2 genetically engineered mice. Diabetes. 2000; 49(3):311-318. [PubMed: 10868950] 
Seino S, Miki T. Physiological and pathophysiological roles of ATP-sensitive K+ channels. Progress in biophysics and molecular biology. 2003; 81(2):133-176. [PubMed: 12565699]

Shi NQ, Ye B, Makielski JC. Function and distribution of the SUR isoforms and splice variants. Journal of molecular and cellular cardiology. 2005; 39(1):51-60. [PubMed: 15978902]

Shi WW, Yang Y, Shi Y, Jiang C. K(ATP) channel action in vascular tone regulation: from genetics to diseases. Sheng li xue bao : [Acta physiologica Sinica]. 2012; 64(1):1-13.

Shyng S, Nichols CG. Octameric stoichiometry of the KATP channel complex. The Journal of general physiology. 1997; 110(6):655-664. [PubMed: 9382894]

Sikka P, Kapoor S, Bindra VK, Saini M, Saxena KK. Iptakalim: A novel multi-utility potassium channel opener. Journal of pharmacology \& pharmacotherapeutics. 2012; 3(1):12-14. [PubMed: 22368410]

Simard JM, Castellani RJ, Ivanova S, Koltz MT, Gerzanich V. Sulfonylurea receptor 1 in the germinal matrix of premature infants. Pediatric research. 2008a; 64(6):648-652. [PubMed: 18679166]

Simard JM, Woo SK, Bhatta S, Gerzanich V. Drugs acting on SUR1 to treat CNS ischemia and trauma. Current opinion in pharmacology. 2008b; 8(1):42-49. [PubMed: 18032110]

Simard JM, Woo SK, Schwartzbauer GT, Gerzanich V. Sulfonylurea receptor 1 in central nervous system injury: a focused review. J Cereb Blood Flow Metab. 2012; 32(9):1699-1717. [PubMed: 22714048]

Smith AJ, Taneja TK, Mankouri J, Sivaprasadarao A. Molecular cell biology of KATP channels: implications for neonatal diabetes. Expert reviews in molecular medicine. 2007; 9(21):1-17. [PubMed: 17666135]

Smith KJ, Chadburn AJ, Adomaviciene A, Minoretti P, Vignali L, Emanuele E, Tammaro P. Coronary spasm and acute myocardial infarction due to a mutation (V734I) in the nucleotide binding domain 1 of ABCC9. International journal of cardiology. 2013; 168(4):3506-3513. [PubMed: 23739550]

Snyder HM, Corriveau RA, Craft S, Faber JE, Greenberg SM, Knopman D, Lamb BT, Montine TJ, Nedergaard M, Schaffer CB, Schneider JA, Wellington C, Wilcock DM, Zipfel GJ, Zlokovic B, Bain LJ, Bosetti F, Galis ZS, Koroshetz W, Carrillo MC. Vascular contributions to cognitive impairment and dementia including Alzheimer's disease. Alzheimers Dement. 2014

Solbach TF, Konig J, Fromm MF, Zolk O. ATP-binding cassette transporters in the heart. Trends in cardiovascular medicine. 2006; 16(1):7-15. [PubMed: 16387624]

Standen NB, Quayle JM. K+ channel modulation in arterial smooth muscle. Acta physiologica Scandinavica. 1998; 164(4):549-557. [PubMed: 9887977]

Stowers JM, Borthwick LJ. Oral hypoglycaemic drugs: clinical pharmacology and therapeutic use. Drugs. 1977; 14(1):41-56. [PubMed: 328260]

Sturm A, Cunningham P, Dean M. The ABC transporter gene family of Daphnia pulex. BMC genomics. 2009; 10:170. [PubMed: 19383151]

Sun XL, Hu G. ATP-sensitive potassium channels: a promising target for protecting neurovascular unit function in stroke. Clin Exp Pharmacol Physiol. 2010; 37(2):243-252. [PubMed: 19413600]

Sun XL, Zeng XN, Zhou F, Dai CP, Ding JH, Hu G. KATP channel openers facilitate glutamate uptake by GluTs in rat primary cultured astrocytes. Neuropsychopharmacology : official publication of the American College of Neuropsychopharmacology. 2008; 33(6):1336-1342. [PubMed: 17609675]

Tanner GR, Lutas A, Martinez-Francois JR, Yellen G. Single K ATP channel opening in response to action potential firing in mouse dentate granule neurons. J Neurosci. 2011; 31(23):8689-8696. [PubMed: 21653873]

Tosun C, Kurland DB, Mehta R, Castellani RJ, deJong JL, Kwon MS, Woo SK, Gerzanich V, Simard JM. Inhibition of the Sur1-Trpm4 channel reduces neuroinflammation and cognitive impairment in subarachnoid hemorrhage. Stroke; a journal of cerebral circulation. 2013; 44(12):3522-3528.

Toyoda K, Fujii K, Takata Y, Ibayashi S, Kitazono T, Nagao T, Fujikawa M, Fujishima M. Agerelated changes in response of brain stem vessels to opening of ATP-sensitive potassium channels. Stroke; a journal of cerebral circulation. 1997; 28(1):171-175. 
Tricarico D, Petruzzi R, Conte Camerino DC. Different sulfonylurea and ATP sensitivity characterizes the juvenile and the adult form of KATP channel complex of rat skeletal muscle. European journal of pharmacology. 1997; 321(3):369-378. [PubMed: 9085050]

Trimmer JS. Subcellular Localization of K Channels in Mammalian Brain Neurons: Remarkable Precision in the Midst of Extraordinary Complexity. Neuron. 2015; 85(2):238-256. [PubMed: 25611506]

Tu IH, Yen HT, Cheng HW, Chiu JH. Baicalein protects chicken embryonic cardiomyocyte against hypoxia-reoxygenation injury via mu- and delta- but not kappa-opioid receptor signaling. European journal of pharmacology. 2008; 588(2-3):251-258. [PubMed: 18511038]

Vajapey R, Rini D, Walston J, Abadir P. The impact of age-related dysregulation of the angiotensin system on mitochondrial redox balance. Frontiers in physiology. 2014; 5:439. [PubMed: 25505418]

van Bon BW, Gilissen C, Grange DK, Hennekam RC, Kayserili H, Engels H, Reutter H, Ostergaard JR, Morava E, Tsiakas K, Isidor B, Le Merrer M, Eser M, Wieskamp N, de Vries P, Steehouwer M, Veltman JA, Robertson SP, Brunner HG, de Vries BB, Hoischen A. Cantu syndrome is caused by mutations in ABCC9. Am J Hum Genet. 2012; 90(6):1094-1101. [PubMed: 22608503]

van Dam RM, Hoebee B, Seidell JC, Schaap MM, de Bruin TW, Feskens EJ. Common variants in the ATP-sensitive K+ channel genes KCNJ11 (Kir6.2) and ABCC8 (SUR1) in relation to glucose intolerance: population-based studies and meta-analyses. Diabetic medicine : a journal of the British Diabetic Association. 2005; 22(5):590-598. [PubMed: 15842514]

Van Deerlin VM, Wood EM, Moore P, Yuan W, Forman MS, Clark CM, Neumann M, Kwong LK, Trojanowski JQ, Lee VM, Grossman M. Clinical, genetic, and pathologic characteristics of patients with frontotemporal dementia and progranulin mutations. Arch Neurol. 2007; 64(8): 1148-1153. [PubMed: 17698705]

Volf N, Hu G, Li M. Iptakalim Preferentially Decreases Nicotine-induced Hyperlocomotion in Phencyclidine-sensitized Rats: A Potential Dual Action against Nicotine Addiction and Psychosis. Clinical psychopharmacology and neuroscience : the official scientific journal of the Korean College of Neuropsychopharmacology. 2012; 10(3):168-179. [PubMed: 23430396]

Walker AK, Daniels CM, Goldman JE, Trojanowski JQ, Lee VM, Messing A. Astrocytic TDP-43 Pathology in Alexander Disease. J Neurosci. 2014; 34(19):6448-6458. [PubMed: 24806671]

Wang H, Long CL, Zhang YL. A new ATP-sensitive potassium channel opener reduces blood pressure and reverses cardiovascular remodeling in experimental hypertension. The Journal of pharmacology and experimental therapeutics. 2005a; 312(3):1326-1333. [PubMed: 15525792]

Wang H, Zhang YL, Chen YP. Targeting small arteries of hypertensive status with novel ATPsensitive potassium channel openers. Current vascular pharmacology. 2005b; 3(2):119-124. [PubMed: 15853631]

Wang H, Zhang YL, Tang XC, Feng HS, Hu G. Targeting ischemic stroke with a novel opener of ATP-sensitive potassium channels in the brain. Molecular pharmacology. 2004; 66(5):11601168. [PubMed: 15304552]

Wang JF, Li Y, Song JN, Pang HG. Role of hydrogen sulfide in secondary neuronal injury. Neurochem Int. 2014; 64:37-47. [PubMed: 24239876]

Wang S, Hu LF, Yang Y, Ding JH, Hu G. Studies of ATP-sensitive potassium channels on 6hydroxydopamine and haloperidol rat models of Parkinson's disease: implications for treating Parkinson's disease? Neuropharmacology. 2005; 48(7):984-992. [PubMed: 15857625]

Wang S, Hu LF, Zhang Y, Sun T, Sun YH, Liu SY, Ding JH, Wu J, Hu G. Effects of systemic administration of iptakalim on extracellular neurotransmitter levels in the striatum of unilateral 6hydroxydopamine-lesioned rats. Neuropsychopharmacology : official publication of the American College of Neuropsychopharmacology. 2006; 31(5):933-940. [PubMed: 16123757]

Weller RO, Hawkes CA, Carare RO, Hardy J. Does the difference between PART and Alzheimer's disease lie in the age-related changes in cerebral arteries that trigger the accumulation of Abeta and propagation of tau? Acta Neuropathol. 2015; 129(5):763-766. [PubMed: 25814152]

Wheeler A, Wang C, Yang K, Fang K, Davis K, Styer AM, Mirshahi U, Moreau C, Revilloud J, Vivaudou M, Liu S, Mirshahi T, Chan KW. Coassembly of different sulfonylurea receptor 
subtypes extends the phenotypic diversity of ATP-sensitive potassium (KATP) channels.

Molecular pharmacology. 2008; 74(5):1333-1344. [PubMed: 18723823]

White L, Petrovitch H, Hardman J, Nelson J, Davis DG, Ross GW, Masaki K, Launer L, Markesbery WR. Cerebrovascular pathology and dementia in autopsied Honolulu-Asia Aging Study participants. Ann N Y Acad Sci. 2002; 977:9-23. [PubMed: 12480729]

Wu CW, Leung CK, Yung WH. Sulphonylureas reverse hypoxia induced K(+)-conductance increase in substantia nigra pars reticulata neurones. Neuroreport. 1996; 7(15-17):2513-2517. [PubMed: 8981414]

Xie J, Duan L, Qian X, Huang X, Ding J, Hu G. K(ATP) channel openers protect mesencephalic neurons against MPP+-induced cytotoxicity via inhibition of ROS production. J Neurosci Res. 2010; 88(2):428-437. [PubMed: 19746425]

Xie X, Cheng T, Wang G, Duan J, Niu W, Xia Q. Genome-wide analysis of the ATP-binding cassette (ABC) transporter gene family in the silkworm, Bombyx mori. Molecular biology reports. 2012; 39(7):7281-7291. [PubMed: 22311044]

Yamada M, Isomoto S, Matsumoto S, Kondo C, Shindo T, Horio Y, Kurachi Y. Sulphonylurea receptor 2B and Kir6.1 form a sulphonylurea-sensitive but ATP-insensitive K+ channel. The Journal of physiology. 1997; 499(Pt 3):715-720. [PubMed: 9130167]

Yang Y, Liu X, Ding JH, Sun J, Long Y, Wang F, Yao HH, Hu G. Effects of iptakalim on rotenoneinduced cytotoxicity and dopamine release from PC12 cells. Neurosci Lett. 2004; 366(1):53-57. [PubMed: 15265589]

Yang Y, Liu X, Long Y, Wang F, Ding JH, Liu SY, Sun YH, Yao HH, Wang H, Wu J, Hu G. Systematic administration of iptakalim, an ATP-sensitive potassium channel opener, prevents rotenone-induced motor and neurochemical alterations in rats. J Neurosci Res. 2005; 80(3):442449. [PubMed: 15795934]

Yang YJ, Zhang S, Ding JH, Zhou F, Hu G. Iptakalim protects against MPP+-induced degeneration of dopaminergic neurons in association with astrocyte activation. The international journal of neuropsychopharmacology / official scientific journal of the Collegium Internationale Neuropsychopharmacologicum. 2009; 12(3):317-327.

Ye B, Kroboth SL, Pu JL, Sims JJ, Aggarwal NT, McNally EM, Makielski JC, Shi NQ. Molecular identification and functional characterization of a mitochondrial sulfonylurea receptor 2 splice variant generated by intraexonic splicing. Circulation research. 2009; 105(11):1083-1093. [PubMed: 19797704]

Yoshida H, Feig JE, Morrissey A, Ghiu IA, Artman M, Coetzee WA. K ATP channels of primary human coronary artery endothelial cells consist of a heteromultimeric complex of Kir6.1, Kir6.2, and SUR2B subunits. Journal of molecular and cellular cardiology. 2004; 37(4):857-869. [PubMed: 15380676]

Yu L, De Jager PL, Yang J, Trojanowski JQ, Bennett DA, Schneider JA. The TMEM106B locus and TDP-43 pathology in older persons without FTLD. Neurology. 2015

Yuan HB, Huang Y, Zheng S, Zuo Z. Hypothermic preconditioning increases survival of purkinje neurons in rat cerebellar slices after an in vitro simulated ischemia. Anesthesiology. 2004; 100(2):331-337. [PubMed: 14739808]

Zarow C, Sitzer TE, Chui HC. Understanding hippocampal sclerosis in the elderly: epidemiology, characterization, and diagnostic issues. Current neurology and neuroscience reports. 2008; 8(5): 363-370. [PubMed: 18713571]

Zarow C, Weiner MW, Ellis WG, Chui HC. Prevalence, laterality, and comorbidity of hippocampal sclerosis in an autopsy sample. Brain and behavior. 2012; 2(4):435-442. [PubMed: 22950047]

Zawar C, Plant TD, Schirra C, Konnerth A, Neumcke B. Cell-type specific expression of ATPsensitive potassium channels in the rat hippocampus. The Journal of physiology. 1999; 514(Pt 2): 327-341. [PubMed: 9852317]

Zhang S, Liang R, Zhou F, Huang X, Ding JH, Hu G. Reversal of rotenone-induced dysfunction of astrocytic connexin 43 by opening mitochondrial ATP-sensitive potassium channels. Cellular and molecular neurobiology. 2011; 31(1):111-117. [PubMed: 20824494]

Zhou F, Wu JY, Sun XL, Yao HH, Ding JH, Hu G. Iptakalim alleviates rotenone-induced degeneration of dopaminergic neurons through inhibiting microglia-mediated neuroinflammation. 
Neuropsychopharmacology : official publication of the American College of Neuropsychopharmacology. 2007; 32(12):2570-2580. [PubMed: 17356569]

Zhou F, Yao HH, Wu JY, Ding JH, Sun T, Hu G. Opening of microglial K(ATP) channels inhibits rotenone-induced neuroinflammation. Journal of cellular and molecular medicine. 2008; 12(5A): 1559-1570. [PubMed: 19012619]

Zhou M, He HJ, Tanaka O, Sekiguchi M, Kawahara K, Abe H. Localization of the ATP-sensitive K(+) channel regulatory subunits SUR2A and SUR2B in the rat brain. Neuroscience research. 2012; 74(2):91-105. [PubMed: 22960600]

Zhou SF, Wang LL, Di YM, Xue CC, Duan W, Li CG, Li Y. Substrates and inhibitors of human multidrug resistance associated proteins and the implications in drug development. Current medicinal chemistry. 2008; 15(20):1981-2039. [PubMed: 18691054]

Zhu HL, Luo WQ, Wang H. Iptakalim protects against hypoxic brain injury through multiple pathways associated with ATP-sensitive potassium channels. Neuroscience. 2008; 157(4):884-894. [PubMed: 18951957]

Zoga V, Kawano T, Liang MY, Bienengraeber M, Weihrauch D, McCallum B, Gemes G, Hogan Q, Sarantopoulos C. KATP channel subunits in rat dorsal root ganglia: alterations by painful axotomy. Molecular pain. 2010; 6:6. [PubMed: 20102598] 


\section{Highlights}

- $\mathrm{ABCC} 9$ encodes SUR2, a metabolic sensor protein that has been shown to change (expression and function) in aging

- $\mathrm{ABCC} 9$ is also strongly implicated in vasoregulation

- ABCC9 has been implicated in neurologic diseases including sleep, depression, and hippocampal sclerosis of aging (HS-Aging)

- HS-Aging is a prevalent and impactful brain disease of advanced old age

- $\mathrm{ABCC} 9 / \mathrm{SUR} 2$ is a potentially druggable target that may provide a future therapeutic strategy 


\section{GENE/PROTEIN}

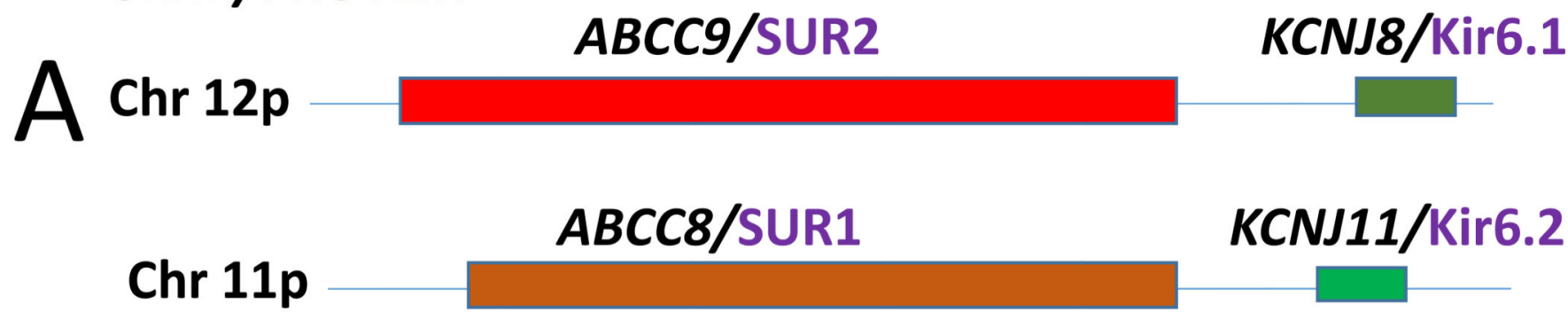

\section{B $\mathrm{K}_{\text {ATP }}$ Channel $\mathrm{C}$}

Regulatory components SUR2 and/or SUR1

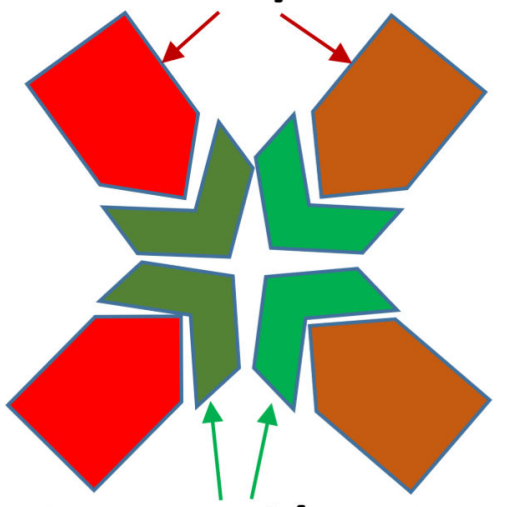

Kir6.1 and/or Kir6.2

Pore-forming components

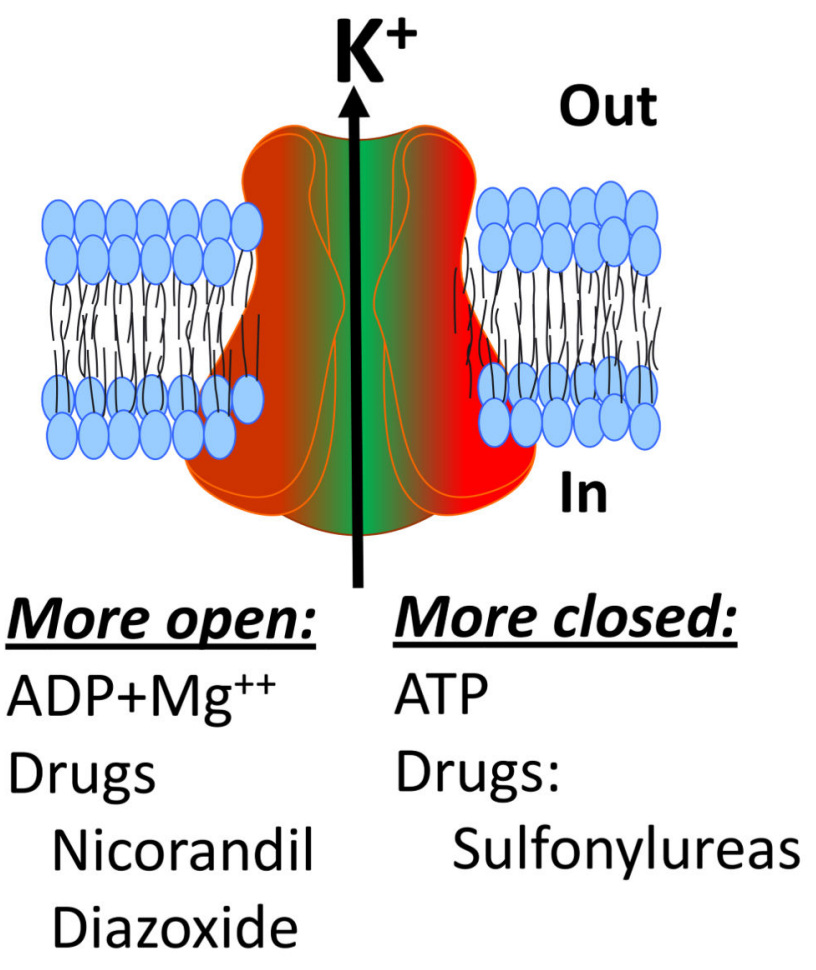

Figure 1. Schematic representation of the genes and proteins that make up the human $K_{A T P}$ channel

A. The $A B C C 9$ gene resides on chromosome $12 p$ and encodes the SUR2 protein.

Approximately 20 kilobases 3' from ABCC9 is the KCNJ8 gene that encodes for the Kir6.1 protein. Paralogous genes on chromosome 11p are $A B C C 8$, which encodes for SUR1

protein, and KCNJ11 which encodes for Kir6.2 protein. B. Studies on crystal structure have elucidated how the $\mathrm{K}_{\mathrm{ATP}}$ channel is organized in the plasma membrane. The $\mathrm{K}_{\mathrm{ATP}}$ channel constitutes a hetero-octamer that includes combinations of 4 SUR1/SUR2 proteins, and 4 Kir6.1/Kir6.2 proteins, with the Kir6.x proteins forming the channel pore. C. When the $\mathrm{K}_{\mathrm{ATP}}$ channel is functionally working in the plasma membrane, it allows $\mathrm{K}+$ ions out and is responsive to ATP/ADP ratio and pharmacological agonists (e.g., nicorandil and diazoxide) and antagonists (sulfonylurea drugs). 


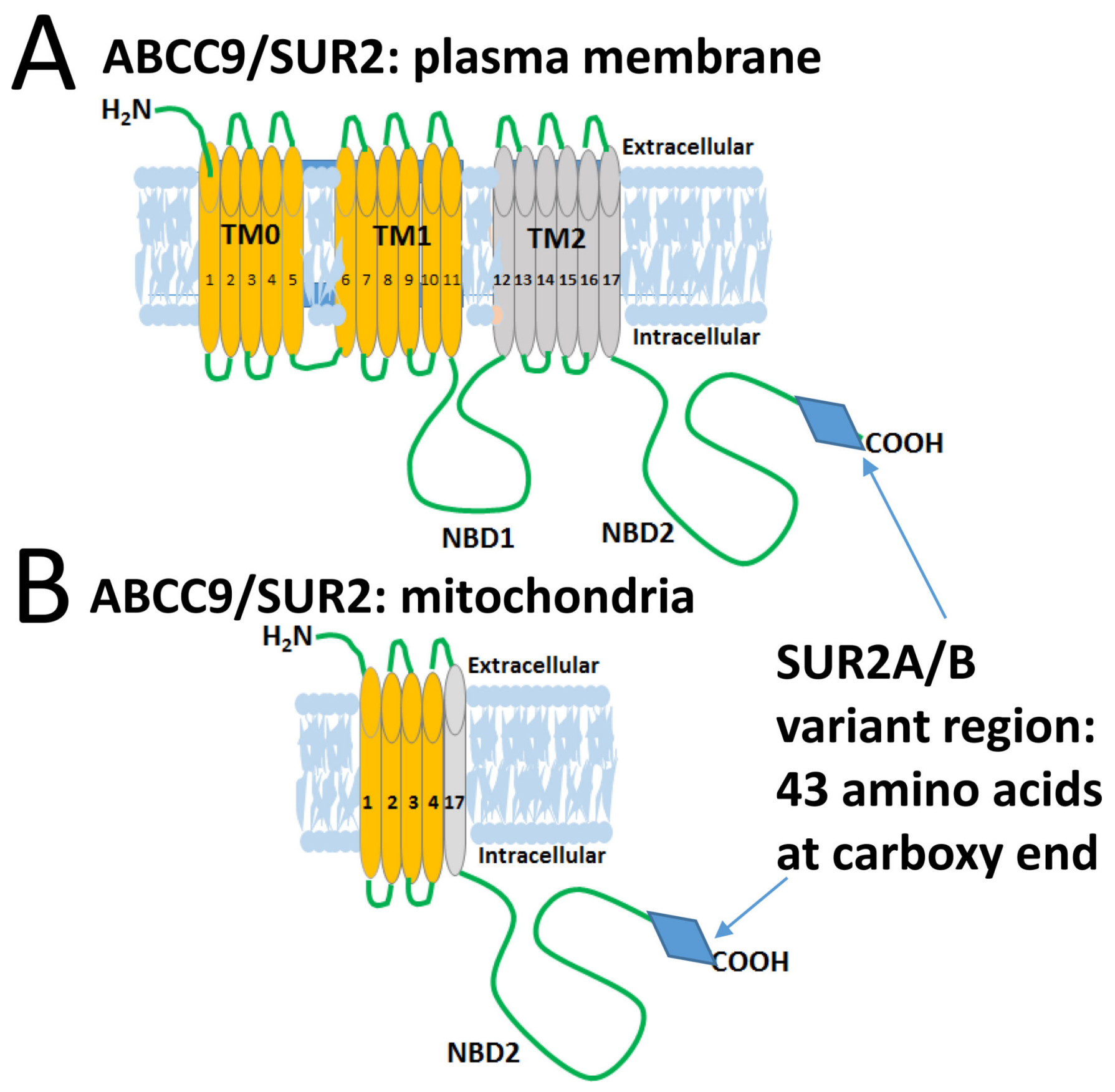

Figure 2. Protein structure of human $A B C C 9$ encoded SUR2 polypeptides These are relatively large proteins $(\sim 150 \mathrm{kDa})$ with multiple membrane-spanning domains. Like all ABCC gene-encoded proteins, SUR2 has two transmembrane ("TMD”) domains, along with two nucleotide-binding ("NBD") domains. A characteristic feature of the sulfonylurea subcategory of ABCC genes is the presence of a third transmembrane domain, TM0. SUR2 has a specialized element in the extreme carboxy end, where two alternatively spliced exons lead to two variants (SUR2A and SUR2B) according to that portion. B. A variant of SUR2 has been described in mitochondria $(\sim 55 \mathrm{kDa})$, shortened as a result of alternative splicing as shown. 


\title{
CLUSTAL analysis and phylogenetic tree depicting protein-level identity to: $H$. Sapiens SUR1/SUR2A/SUR2B
}

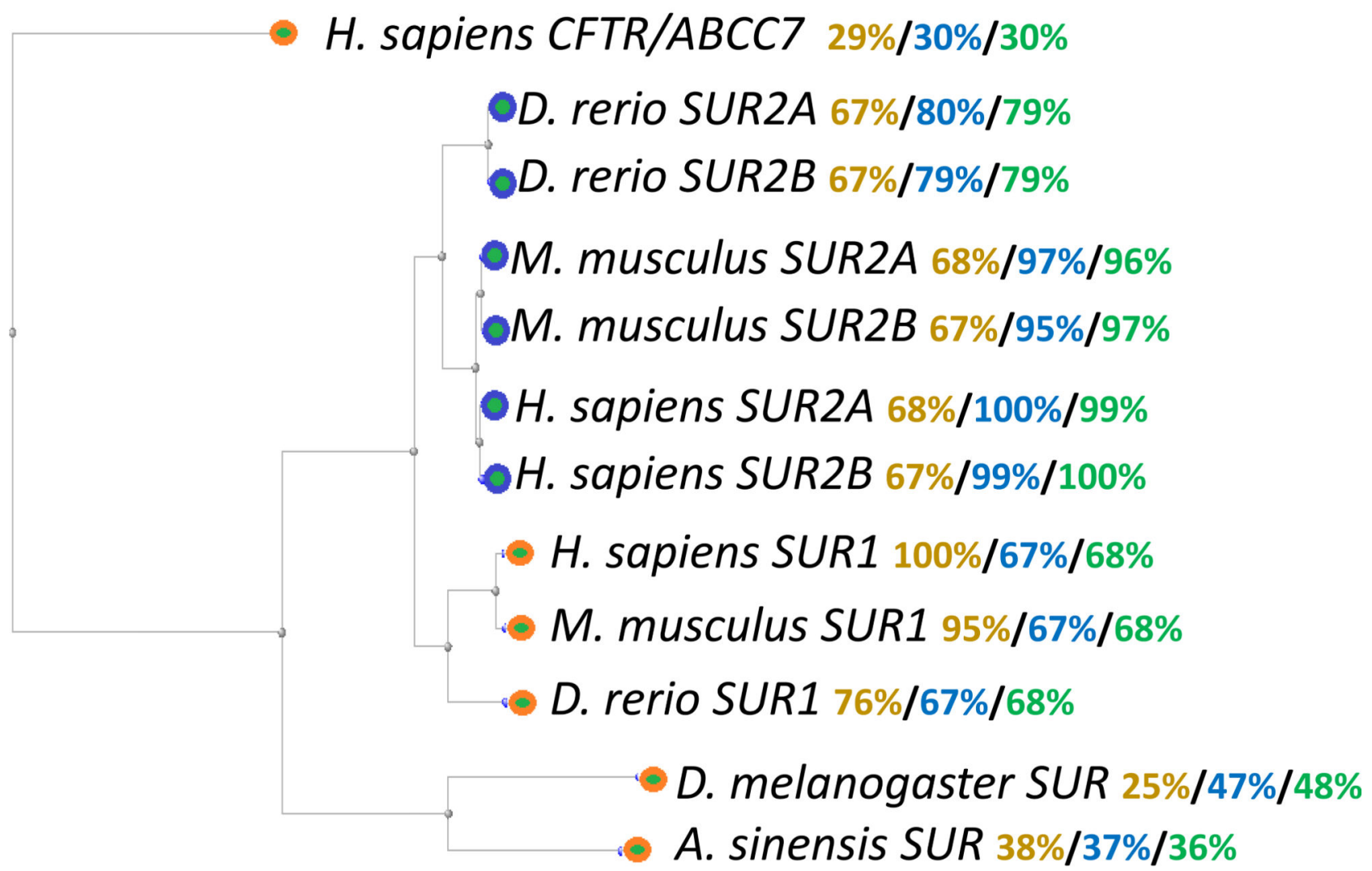

\section{- $A B C C 9$ and direct vertebrate orthologs -both SUR2A and SUR2B are proteins encoded by ABCC9}

\section{Other "ABCC" orthologs}

\section{-SUR1 is encoded by ABCC8}

\begin{abstract}
Figure 3. Phylogenetic tree provides background on evolution and protein-level identity with paralogous proteins

Shown is the result of a phylogenetic tree generated by comparing the protein-level sequences of $\mathrm{ABCC}$ proteins using the Web-based alignment tool (http://

blast.ncbi.nlm.nih.gov/blast). Also shown for each species/gene in the tree is the protein level percent identity for human full-length SUR1/SUR2A/SUR2B proteins. Each of these genes is relatively well-conserved in vertebrate species. Further, there are invertebrate orthologs (shown are SUR protein data related to fruit flies and mosquitos) that appear more homologous to human SUR2 than to SUR1 proteins. For comparison, a presumed ortholog
\end{abstract}


is included in the phylogenetic tree: the human $A B C C$ gene $C F T R / A B C 7$. This is the gene responsible for the most common lethal human genetic disease, cystic fibrosis (Riordan, et al., 1989). 


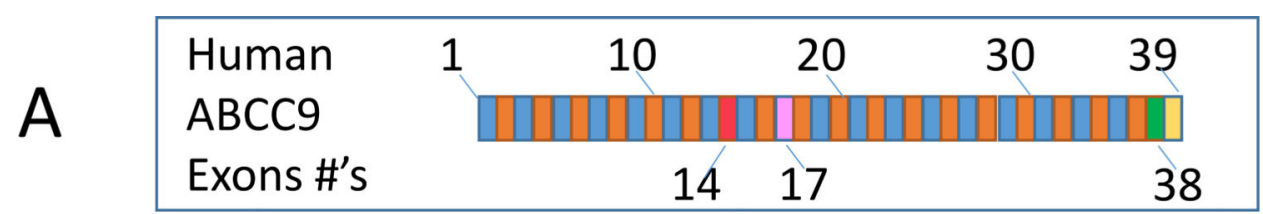
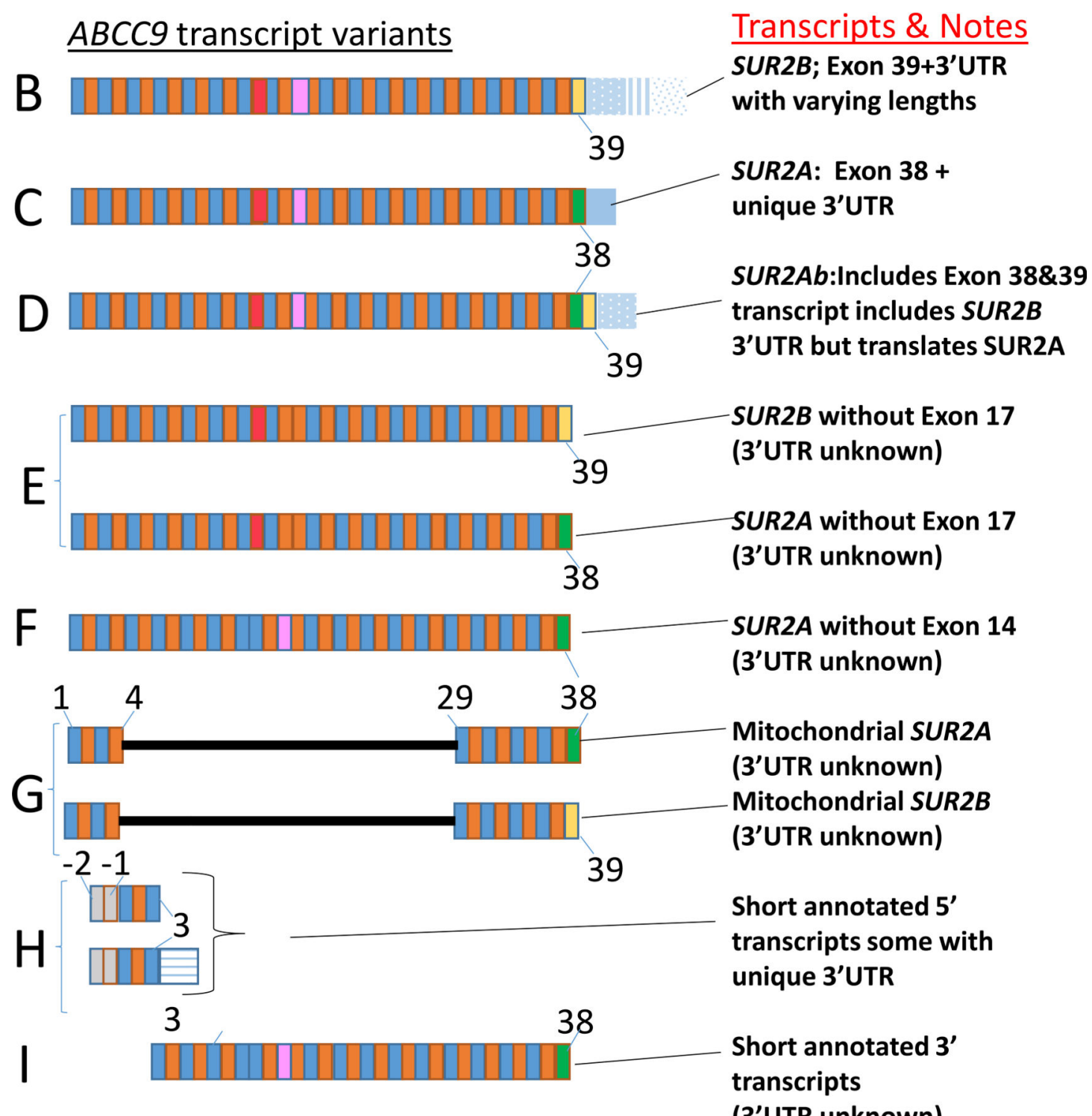

See Figure legend for transcript IDs

(3'UTR unknown)

Figure 4. Alternative splicing in humans is complex, leading to multiple variants of SUR2 transcripts and proteins(Shi, et al., 2005)

A. Basic genomic structure of $A B C C 9$ includes at least 39 potential exons, not including untranslated regions (UTRs). B. Transcript designated "SUR2B" (ENST00000261200) includes Exon 39 but not Exon 38. This transcript incorporates 3' UTR regions of varying lengths which may affect transcript(s) stability. C. Transcript designated "SUR2A"

(ENST0000026120) includes Exon 38 but not Exon 39 and was recently described to have an unique 3'UTR from genomic sequence immediately downstream from Exon 38 (al). D. A separate transcript, designated "SUR2Ab" (not yet annotated) incorporates both Exon 38 
and Exon 39; whereas this transcript is translated similar to "SUR2A", it harbors the 3'UTR that is associated with SUR2B transcript (al). E. Human SUR2A- and SUR2B-like clones have been characterized that do not include Exon 17 (NM_005691 and NM_020297) (Davis-Taber, et al., 2000). F. Human SUR2A-like clones were characterized that do not include Exon 14 (NM_020298). G. Transcripts that produce SUR2-like proteins in mitochondrial lack a large portion (from Exons 4-29) but may incorporate either Exon 38 or Exon 39 (Ye, et al., 2009). Transcripts that have been annotated, but not functionally characterized, which include exons exclusively from either the 5' portion $(\mathrm{H})$ or the 3' portion (I) of the $A B C C 9$ gene (ENST00000544039,ENST00000538350, and ENST00000326684). 


\section{Physiologic role(s) of $\mathrm{K}_{\text {ATP }}$ channel: respond to hypoxia and stressors}

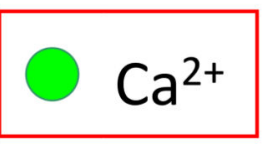

\section{STRESS/ HYPOXIA/}

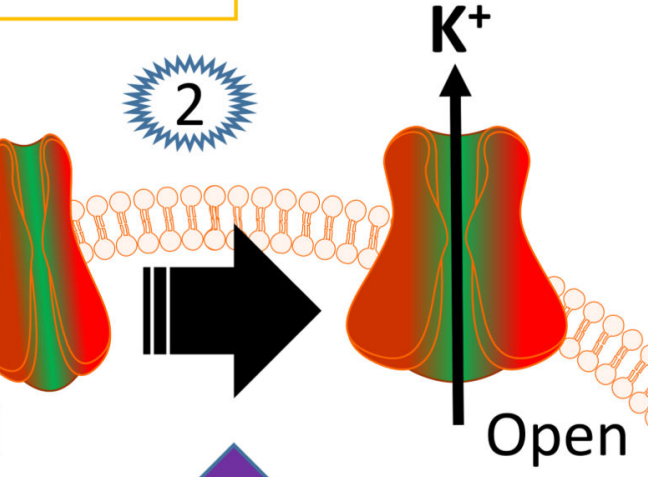

\section{$\mathrm{H} 2 \mathrm{O} 2$}
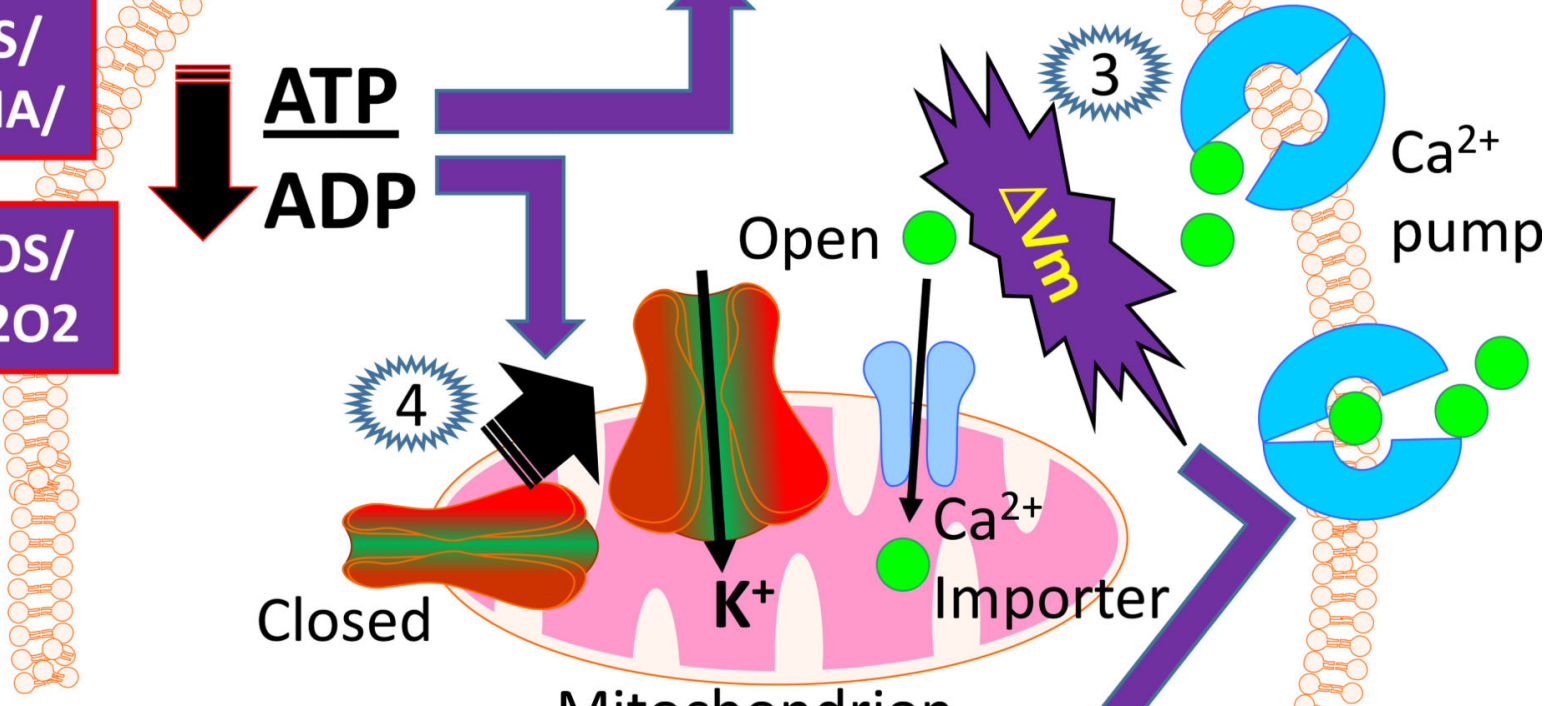

Closed
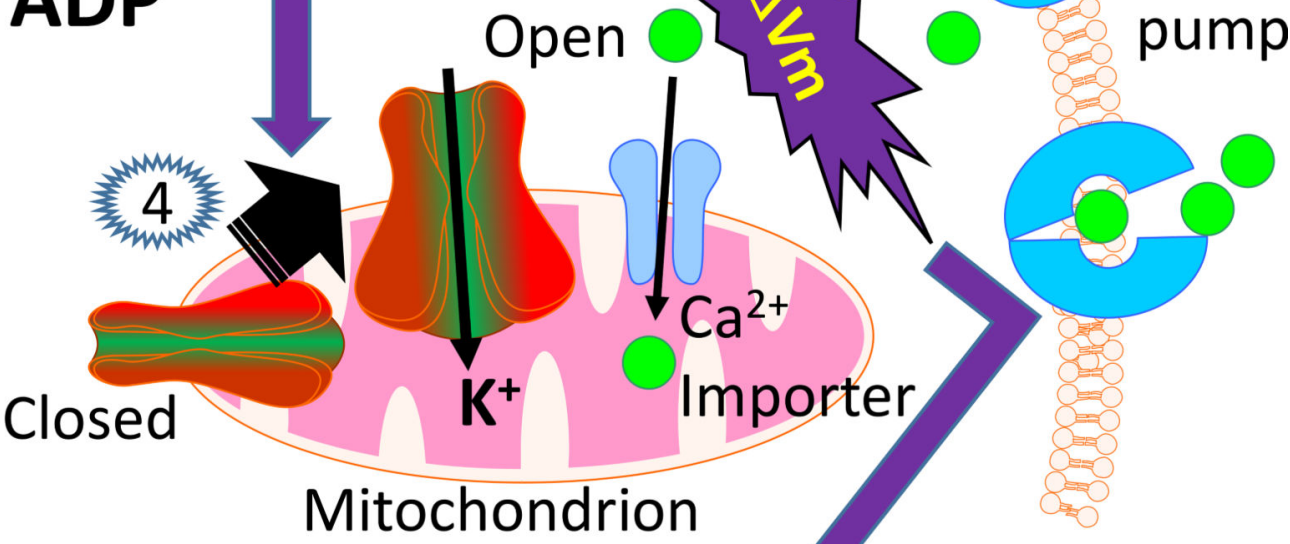

Figure 5. Mechanistic progression associated with SUR2 in a generic cell-type

1. Stressors and/or hypoxia lead to decreased intracellular ATP/ADP ratio. 2. At the plasma membrane, the ATP/ADP ratio, as well as other messengers not shown, can shift the $\mathrm{K}_{\mathrm{ATP}}$ channel from a closed to open configuration, leading to $\mathrm{K}+$ ions leaving the cell. 3 . The $\mathrm{K}+$ ions alter (reduce) the membrane depolarization leading to shift in the voltage-gated $\mathrm{Ca}++$ pump dynamics. 4. In mitochondria, overlapping signals can affect the local mitochondria and mitochondrial SUR2, which is currently imperfectly understood but which also can alter mitochondrial $\mathrm{Ca}++$ processing and energy production. 5. A key net outcome of SUR2 function and $\mathrm{K}_{\mathrm{ATP}}$ channel opening is to decrease local intracellular $\mathrm{Ca}++$ levels which can buffer the impact of the stress/hypoxic challenge. 


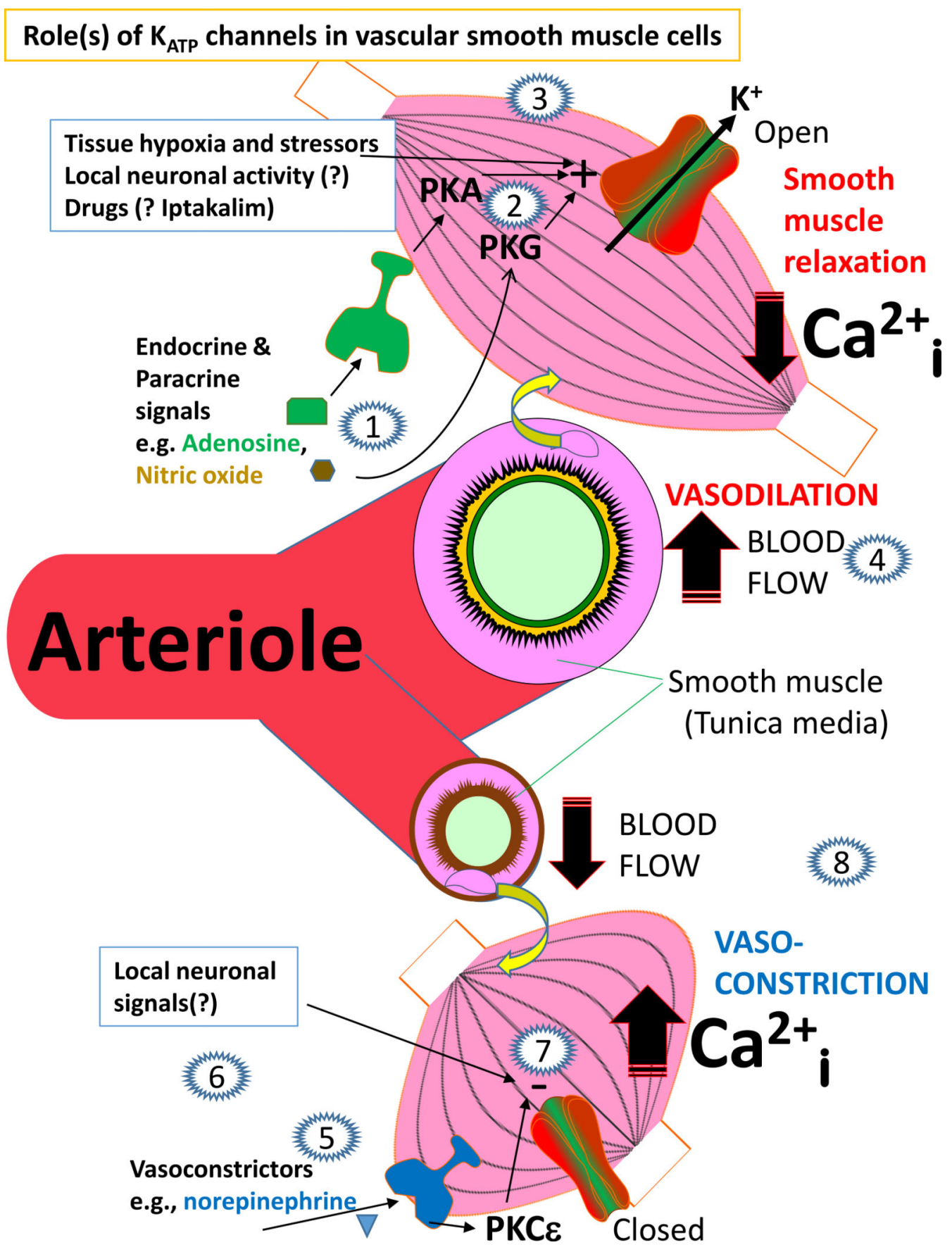

Figure 6. SUR2 and $\mathrm{K}_{\mathrm{ATP}}$ channels play key roles regulating arteriolar function including vasodilation (1-5) and vasoconstriction (6-8)

1. Blood-borne vasodilatory agents (adenosine, nitric oxide, and others) can function through either membrane receptors (e.g., adenoside) or by diffusible (nitric oxide) mechanisms. 2. Intracellular second messengers including protein kinase A (PKA) can phosphorylate SUR2 and promote $\mathrm{K}_{\mathrm{ATP}}$ channel opening. 3. It is not well understood how local brain ischemia/hypoxia, or local neuronal excitability, may also promote $\mathrm{K}_{\mathrm{ATP}}$ channel opening in vivo. 4 . The $\mathrm{K}_{\mathrm{ATP}}$ channel promotes decreased intracellular $\mathrm{Ca}^{++}$, vasodilation, and increased local blood flow. 5. By contrast, other signals can promote vasoconstriction, 
including norepinephrine. 6. One pathway to promote smooth muscle contraction through $\mathrm{K}_{\mathrm{ATP}}$ channel mechanism is the PKCe. 7. Other brain-specific pathways including neuronal signaling may also lead to $\mathrm{K}_{\mathrm{ATP}}$ channel closing. 8. The net effect of $\mathrm{K}_{\mathrm{ATP}}$ channel closing is to increase intracellular $\mathrm{Ca}^{++}$, contract smooth muscle in the tunica media of arterioles, and decrease local blood flow. This figure incorporates information from recent reviews (Flagg, et al., 2010,Ko, et al., 2008). Here we show cartoon depiction of the $\mathrm{K}_{\mathrm{ATP}}$ channel in smooth muscle cells but it should be kept in mind that $\mathrm{K}_{\mathrm{ATP}}$ channels have also been shown to affect endothelial cells, pericytes, and possibly perivascular astrocytes. 


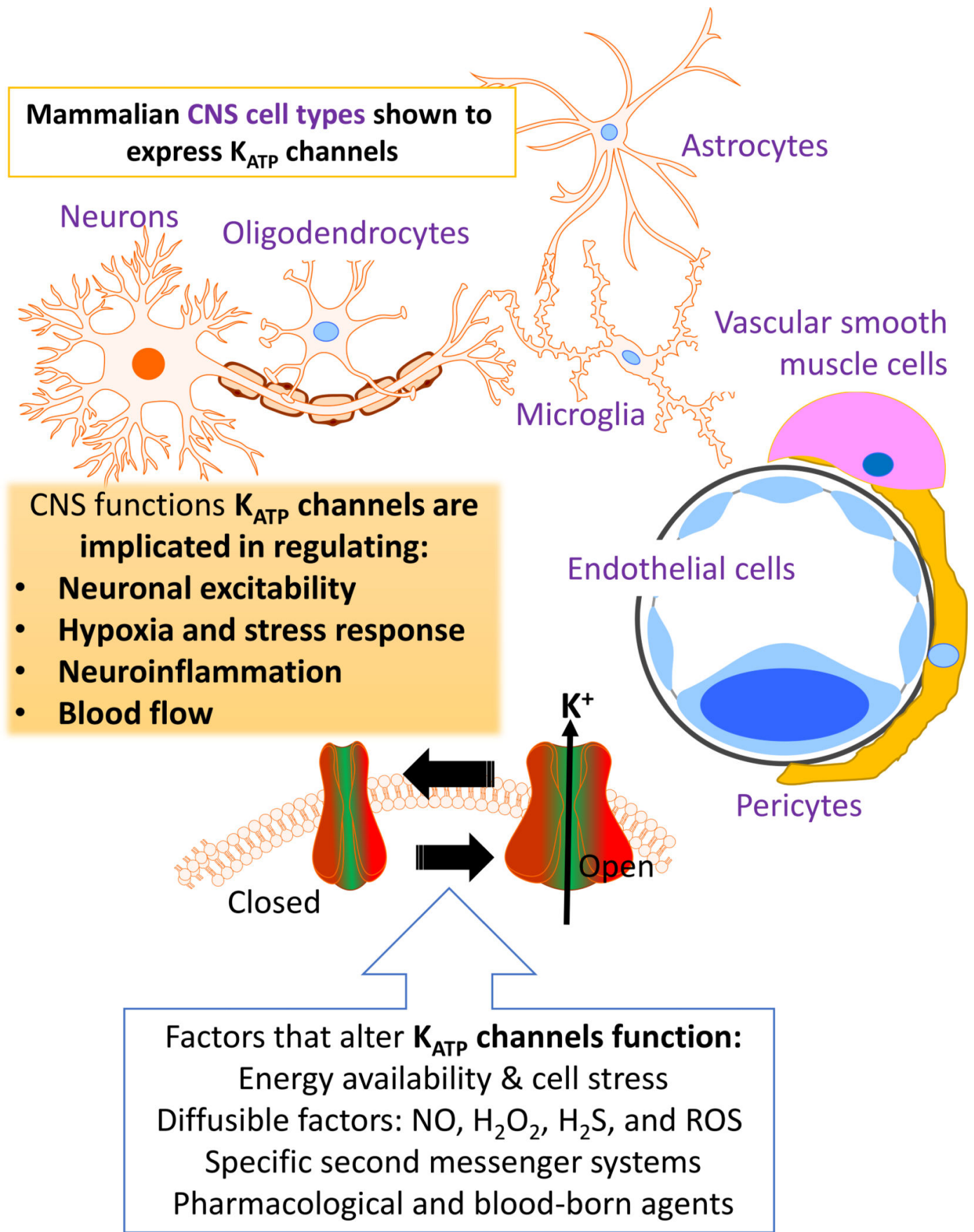

Figure 7. $K_{A T P}$ channels have been described in just about every cell type of the human brain The interplay of $\mathrm{K}_{\mathrm{ATP}}$ channels, alongside the many other subtypes of $\mathrm{K}+$ channels, in the human brain is extremely complex. These channels play important roles in regulating neuronal excitability, stress response, neuroinflammation, and blood flow. Thus these $\mathrm{K}_{\mathrm{ATP}}$ channels are candidates for involvement in human brain diseases when they are dysfunctional. Increasing evidence is accumulating to highlight the brain conditions where $\mathrm{K}_{\mathrm{ATP}}$ channel may be relevant. 

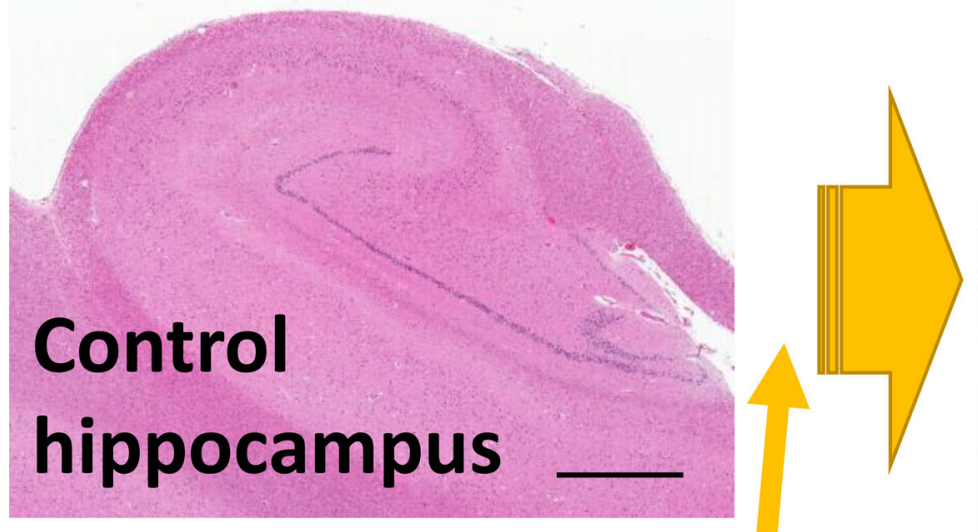

\section{HS-Aging}

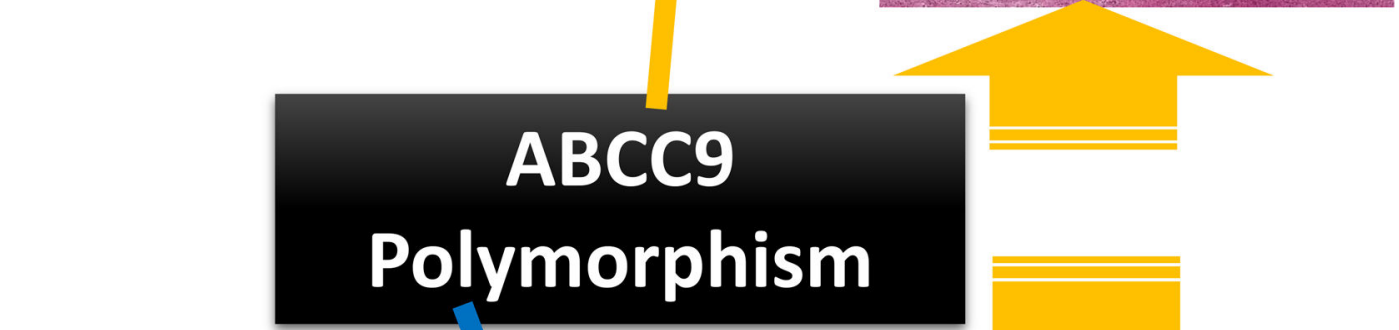

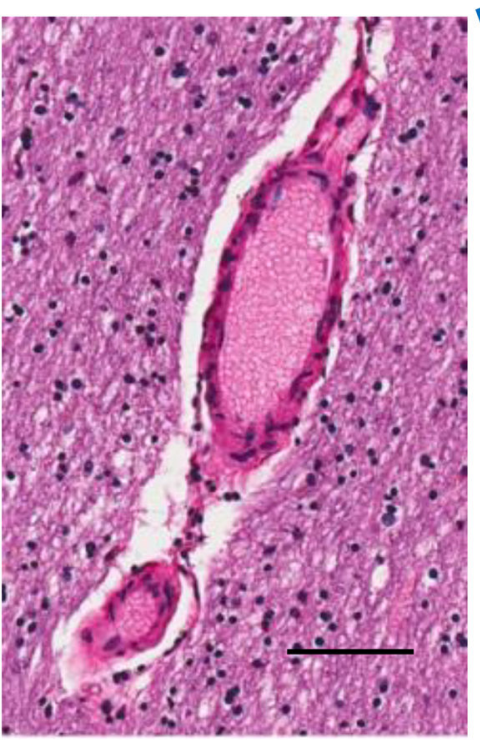

Arteriole
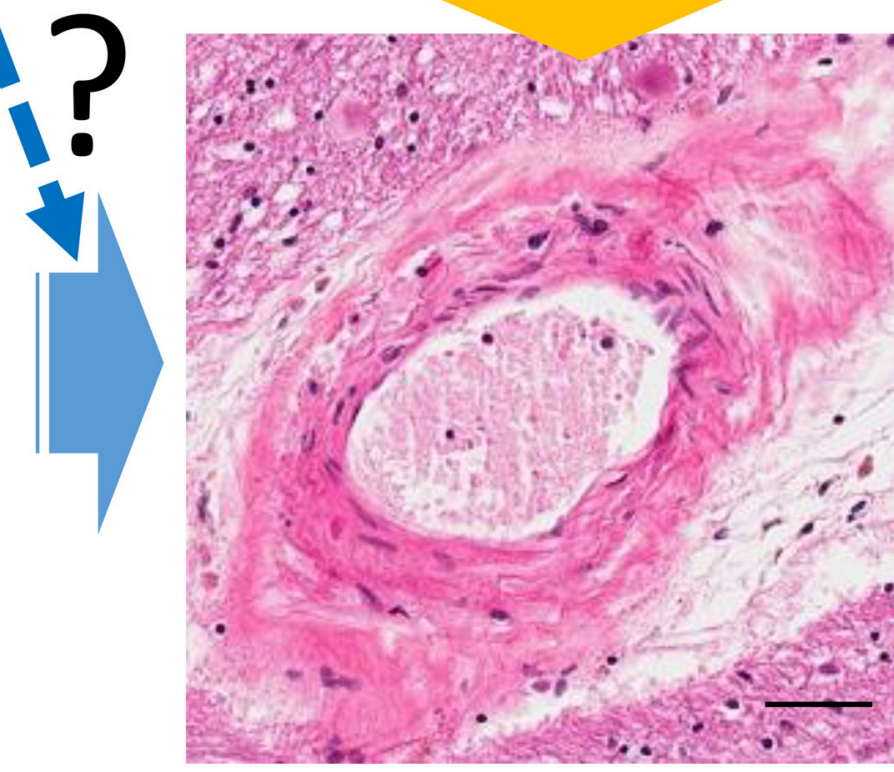

Arteriolosclerosis

Figure 8. A polymorphism in $A B C C 9$ showed genome-wide statistically significant association with hippocampal sclerosis of aging (HS-Aging) as a GWAS endophenotype (Haug, et al., 2015, Nelson, et al., 2014)

HS-Aging is a prevalent neurodegenerative condition affecting the "oldest-old" and characterized by cell loss and atrophy in the hippocampal formation not due to Alzheimer's disease-type pathways. Another factor associated with HS-Aging pathology is arteriolosclerosis, a pathological change where normal arterioles become dysmorphic (as shown in the Figure). Whether and how these observations are connected currently is unknown. Given the known expression of $A B C C 9$ in vascular smooth muscle cells, a 
parsimonious hypothesis is that long-term $A B C C 9$ dysregulation may contribute to brain arteriolar injury (arteriolosclerosis) which in turns potentiates the manifestation of HS-

Aging pathology. Scale bars $=1 \mathrm{~mm}$ for A, B. 100 microns for C, D. 


\section{Table 1}

Cantu syndrome cases reported to date, with $(n=28)$ and without $(n=19)$ documented neurological conditions

\begin{tabular}{|c|c|c|c|}
\hline Paper & \# Cases & Notable human CNS findings & (Ref) \\
\hline Cantu et al, 1982 & 2 & $1 / 2$ with mild mental retardation/delay & (Cantu, et al., 1982) \\
\hline Nevin et al, 1996 & 1 & Developmentally normal boy & (Nevin, et al., 1996) \\
\hline D. García-Cruz et al, 1997 & 4 & $\begin{array}{l}\text { "Mild mental retardation" in } 3 / 4 \text {, "enlarged posterior } \\
\text { fossa" in } 4 / 4 .\end{array}$ & (Garcia-Cruz, et al., 1997) \\
\hline Rosser et al, 1998 & 3 & Developmental delay noted in $2 / 3$ cases & (Rosser, et al., 1998) \\
\hline S.P. Robertson et al, 1999 & 2 & $\begin{array}{l}\text { Developmental delay/mild mental retardation in both } \\
\text { cases }\end{array}$ & (Robertson, et al., 1999) \\
\hline D Concolino et al, 2000 & 1 & "Psychomotor development was normal" & (Concolino, et al., 2000) \\
\hline B Lazalde et al, 2000 & 4 & No specific mention of neurological disorders & (Lazalde, et al., 2000) \\
\hline H. Engels et al, 2002 & 1 & $\begin{array}{l}\text { Brain atrophy and ultrasound- confirmed "bilateral } \\
\text { calcification of the Arteriae thalamostriatae" }\end{array}$ & (Engels, et al., 2002) \\
\hline D.K. Grange et al, 2006 & $\begin{array}{l}\text { Woman and two } \\
\text { daughters }\end{array}$ & No mention of cognitive or cerebral anomaly & (Grange, et al., 2006) \\
\hline C. Graziado et al, 2010 & 1 & "mildly delayed psychomotor development" & (Graziadio, et al., 2011) \\
\hline I. Scurr et al, 2010 & 9 & Motor or speech delay in $9 / 10$ cases & (Scurr, et al., 2011) \\
\hline Kobayashi et al, 2010 & 1 & Clinical syndrome included "developmental delay" & (Kobayashi, et al., 2010) \\
\hline J.C. Czeschik et al, 2012 & 2 & $\begin{array}{l}\text { Both with ABCC9 mutations, } 1 / 2 \text { with mild } \\
\text { developmental delay }\end{array}$ & (Czeschik, et al., 2013) \\
\hline $\begin{array}{l}\text { C.L. Garcia-Gonzalez et al, } \\
2012\end{array}$ & 1 & $\begin{array}{l}\text { Delayed psychomotor development with cerebral cortical } \\
\text { atrophy on CT scan }\end{array}$ & $\begin{array}{l}\text { (Garcia-Gonzalez, et al., } \\
\text { 2012) }\end{array}$ \\
\hline $\begin{array}{l}\text { W.M. van Bon Bregjie et } \\
\text { al, } 2012\end{array}$ & $\begin{array}{c}9 \text { previously } \\
\text { unpublished, } 1 \\
\text { father/daughter, } 1 \\
\text { sib pair }\end{array}$ & $\begin{array}{l}\text { All with ABCC } 9 \text { mutations, } 3 \text { diagnosed with intellectual } \\
\text { disability and/or developmental delay, } 8 / 9 \text { with } \\
\text { macrocephaly }\end{array}$ & (van Bon, et al., 2012) \\
\hline Y. Hiraki et al, 2013 & Father and son & $\begin{array}{l}\text { "mild psychomotor delay ... and an autistic disorder } \\
\text { based on the DSM-IV" }\end{array}$ & (Hiraki, et al., 2014) \\
\hline J.Y. Park et al, 2014 & 1 & $\begin{array}{l}\text { ABCC9 mutation (p.Ala1462Gly, c. } 4385 \mathrm{C}>\mathrm{G} \text { ) } \\
\text { confirmed; atrophic changes of the brain on MRI }\end{array}$ & (Park, et al., 2014) \\
\hline
\end{tabular}


Table 2

Clinical conditions and their associations with specific $A B C C 9$ mutations

\begin{tabular}{|c|c|c|c|}
\hline $\begin{array}{l}\text { Clinical condition/ } \\
\text { endophenotype }\end{array}$ & $\begin{array}{l}\text { Mutation } \\
\text { Type* }\end{array}$ & Notes & (Refs) \\
\hline Cantu syndrome & $\mathrm{E}, \mathrm{I}$ & $\begin{array}{l}\text { Apparent autosomal dominant inheritance of functional } \\
\text { gain of toxic function; many mutations identified, mostly } \\
\text { in exons coding transmembrane domains of SUR2 protein }\end{array}$ & $\begin{array}{l}\text { (Harak alova, et al., 2012, } \\
\quad \text { van Bon, et al., 2012) }\end{array}$ \\
\hline Atrial fibrillation & $\mathrm{E}$ & $\begin{array}{l}\text { Case of mutation [Thr1547Ile] associated with atrial } \\
\text { fibrillation originating in the vein of Marshal }\end{array}$ & (Olson, et al., 2007) \\
\hline Dilated cardiomyopathy & $\mathrm{E}$ & $\begin{array}{l}\text { Two cases with distinct mutations [frameshift1524, } \\
\text { A1513T] associated with dilated cardiomyopathy }\end{array}$ & $\underset{\text { (Bienen graeber, et al., }}{\text { (2004) }}$ \\
\hline $\begin{array}{l}\text { Myocardial infarction, early } \\
\text { repolarization syndrome (ERS), } \\
\text { and Brugada syndrome }(\mathrm{BrS})\end{array}$ & $\mathrm{E}$ & $\begin{array}{l}\text { Coronary arterial vasospam and myocardial infarction } \\
\text { linked to V734I mutation. Severe cardiac arrhythmias } \\
\text { associated with } 8 A B C C 9 \text { mutations from } 11 \mathrm{BrS} \text { probands } \\
\text { and } 4 \text { ERS probands, the latter with V734I mutations. }\end{array}$ & $\begin{array}{l}\text { (Baraja s-Martine z, et al., } \\
\text { 2012, Beziau, et al., 2014, } \\
\text { Hu, et al., 2014, Minoretti, et } \\
\text { al., 2006, Smith, et al., 2013) }\end{array}$ \\
\hline Sleep disorder & I & $\begin{array}{c}A B C C 9 \text { SNP rs11046205 and rs11046209 showed some } \\
\text { association with sleep duration, but with some variation } \\
\text { between studies }\end{array}$ & $\begin{array}{l}\text { (Allebr andt, et al., 2013), } \\
\text { (Parsons, et al., 2013) }\end{array}$ \\
\hline Depression & I & $\begin{array}{l}A B C C 9 \text { SNP rs11046205 was associated with depressive } \\
\text { symptoms }\end{array}$ & (Parsons, et al., 2013) \\
\hline $\begin{array}{l}\text { Hippocampal sclerosis of aging } \\
\text { (HS-Aging) }\end{array}$ & I & $\begin{array}{l}\text { GWAS with genome-wide statistical significance and } \\
\text { separate replication study show association between HS- } \\
\text { Aging and a group of intronic SNPs that include rs } 704180\end{array}$ & $\begin{array}{l}\text { (Nelson, et al., 2014, } \\
\text { Nelson, et al., 2015) }\end{array}$ \\
\hline Blood pressure/hypertension & I & $\begin{array}{c}A B C C 9 \text { SNPs were associated with angiotensin II receptor } \\
\text { blocker medication response }\end{array}$ & (Kamide, et al., 2013) \\
\hline Blood pressure/hypertension & I & $\begin{array}{c}\text { A haplotype (ABCC } 9 \text { SNP combination) is associated with } \\
\text { risk for essential hypertension }\end{array}$ & (Sato, et al., 2006) \\
\hline Entorhinal cortex thinning & G & $\begin{array}{l}\text { SNP rs10743430 is } \sim 50,000 \text { bases upstream from } A B C C 9 \\
\text { In GWAS for MRI-detected atrophy; p 6E-7. }\end{array}$ & (Furney, et al., 2011) \\
\hline Hirschprung disease & I & $\begin{array}{c}\text { Top SNP (rs704192) is in linkage disequilibrium with HS- } \\
\text { Aging risk SNPs }\end{array}$ & (Kim, et al., 2014) \\
\hline
\end{tabular}

*xonic (E), Intronic (I), Intergenic (G) 